\title{
msitit \\ SAFETY ANALYSIS REPORT USE OF H-451 GRAPHITE IN FORT ST. VRAIN FUEL ELEMENTS
}

\author{
$95^{00^{44^{9}}}$ \\ GENERAL ATOMIC COMPANY \\ DECEMBER 20, 1977
}




\section{DISCLAIMER}

This report was prepared as an account of work sponsored by an agency of the United States Government. Neither the United States Government nor any agency Thereof, nor any of their employees, makes any warranty, express or implied, or assumes any legal liability or responsibility for the accuracy, completeness, or usefulness of any information, apparatus, product, or process disclosed, or represents that its use would not infringe privately owned rights. Reference herein to any specific commercial product, process, or service by trade name, trademark, manufacturer, or otherwise does not necessarily constitute or imply its endorsement, recommendation, or favoring by the United States Government or any agency thereof. The views and opinions of authors expressed herein do not necessarily state or reflect those of the United States Government or any agency thereof. 


\section{DISCLAIMER}

Portions of this document may be illegible in electronic image products. Images are produced from the best available original document. 
CONTENTS

1. INTRODUCTION AND SUMMARY . . . . . . . . . . . . . . . 1-1

2. PERFORMANCE ANALYSIS . . . . . . . . . . . . . . . . . 2-1

2.1. Core Nuclear Analysis . . . . . . . . . . . 2-1

2.1.1. Fuel Loading and Excess Reactivity.... . 2-1

2.1.2. Power Distribution ........... 2-1

2.1.3. Fuel Burnup and Exposure......... 2-2

2.1.4. Shutdown Margins and Reactor Control . . . . 2-2

2.1.5. Rod Withdrawal Accidents . . . . . . 2-2

2.2. Core Thermal Analysis . . . . . . . . . . . . 2-2

2.3. Fission Product Transport Analysis . . . . . . . 2-3

2.4. Graphite Structural Analysis . . . . . . . . . . . 2-4

2.4.1. Mechanical Properties. . . . . . . 2-4

2.4.2. Stress Analysis ........... . 2-5

2.4.3. Graphite Dimensional Change ...... 2-7

References . . . . . . . . . . . . . . . 2-8

3. SAFETY ANALYSIS ................. . . . . . . .

3.1. Introduction and Summary ............. . 3-1

3.2. Loss of Normal Shutdown Cooling . . . . . . . . 3-2

3.3. Moisture Inleakage . . . . . . . . . . 3-2

3.3.1. Steam-Graphite Reactions . . . . . . . 3-3

3.3.2. Hydrolysis of Failed Fuel . . . . . . . 3-4

3.3.3. Fission Product Release from Oxidized
Graphite.............. 3-4

3.4. Permanent Loss of Forced Cooling . . . . . . . . 3-5

3.5. Rapid Depressurization/Blowdown . . . . . . . . 3-6

3.6. Conclusions . . . . . . . . . . . . 3-8

References ................... . . 3-8

4. MATERIALS PROPERTY DATA ................. . . . 4-1

4.1. H-451 Graphite Materials Property Data . . . . . . . 4-1

4.1.1. Specific Heat .. . . . . . . . . 4-1 
4.1.2. Bulk Density ............. . . 4-1

4.1.3. Irradiation-Induced Dimensional Change . . . 4-1

4.1.4. Ultimate Tensile Strength ....... . 4-2

4.1.5. Ultimate Compressive Strength ....... 4-2

4.1.6. Elastic Modulus. . . . . . . . . . 4-2

4.1.7. Poisson's Ratio ............ 4-3

4.1.8. Irradiation Creep Behavior . . . . . . . 4-3

4.1.9. Thermal Expansion ............ 4-3

4.1.10. Thermal Conductivity . . . . . . . . . 4-4

4.2. H-327 Graphite Materials Property Data . . . . . . 4-6

4.2.1. Specific Heat. . . . . . . . . . 4-6

4.2.2. Bulk Density ............. 4-7

4.2.3. Irradiation-Induced Dimensional Change . . 4-7

4.2.4. Ultimate Tensile Strength . . . . . . . 4-8

4.2.5. Ultimate Compressive Strength . . . . . 4-8

4.2.6. Elastic Modulus . . . . . . . . . 4-8

4.2.7. Poisson's Ratio ............ . 4-8

4.2.8. Irradiation-Induced Creep . . . . . . . 4-8

4.2.9. Thermal Expansivity . . . . . . . . . 4-9

4.2.10. Thermal Conductivity .......... 4-9

References ................... . 4-10

\section{FIGURES}

4-1. Irradiation strain versus fast neutron fluence and irradiation temperature in near-isotropic graphite; axial

orlentation .................... . 4-21

4-2. Irradiation strain versus fast neutron fluence and irradiation temperature in near-isotropic graphite; radial orientation ... . . . . . . . . . 4-22

4-3. Thermal strain (expansion) of H-451 near-isotropic graphite .. . . . . . . . . . . . . . . . 4-23

4-4. Thermal conductivity of irradiated H-451 graphite . . . . . 4-24

4-5. Irradiation-induced dimensional change . . . . . . . 4-25

4-6. H-327 graphite thermal expansion from data given in Table 4-10 .................. . 4-27

4-7. Calculated thermal conductivity of irradiated $\mathrm{H}-327$ needle-coke graphite .. . . . . . . . . . 4 4-28 
2-1. Comparison of maximum initial operating and shutdown tensile stresses in the $\mathrm{H}-451$ and $\mathrm{H}-327$ fuel elements in the original core... . . . . . . . . . . . . . . 2-9

3-1. Potential effects of H-451 graphite on FSV FSAR accident predictions . . . . . . . . . . . . . . . . . 3-9

4-1. Coefficients for irradiation strain polynomial, H-451 graphite ..................... . 4 4-12

4-2. U1timate tensile strength of unirradiated $\mathrm{H}-451$ graphite at $25^{\circ} \mathrm{C}$................. . . . 4-13

4-3. Elastic modulus of unirradiated $\mathrm{H}-451$ graphite at $25^{\circ} \mathrm{C}$. . . 4-13

4-4. Thermal expansion of H-451 graphite. . . . . . . . . . . 4-14

4-5. Temperature-dependent conductivity components . . . . . . 4-15

4-6. Material constants for calculation of near-isotropic graphite thermal conductivity . . . . . . . . . . 4-16

4-7. Coefficients for irradiation strain polynomial, $\mathrm{H}-327$ graphite . . . . . . . . . . . . . . . . 4-17

4-8. Ultimate tensile strength of unirradiated H-327 graphite. . . 4-18

4-9. Elastic modulus of unirradiated H-327 graphite . . . . . 4-18

4-10. Thermal expansion of $\mathrm{H}-327$ graphite . . . . . . . . . 4-19

4-11. Material constants for calculation of H-327 thermal conductivity ................ . . 4-20 


\section{INTRODUCTION AND SUMMARY}

This Safety Analysis Report (SAR) evaluates the use of H-451 graphite in future reload segments for the Fort St. Vrain (FSV) Nuclear Generating Station. It is proposed to replace the reference core $\mathrm{H}-327$ graphite fuel and replaceable reflector elements with $\mathrm{H}-451$ graphite elements as each segment is reloaded. This report presents the pertinent properties of the H-451 graphite material, the operational behavior of the H-451 graphite elements, and the effect on postulated accidents described in the FSV Final Safety Analysis Report (FSAR).

The H-451 fuel and replaceable reflector elements will be fabricated and assembled by General Atomic (GA) according to specifications and quality requirements comparable to those used for manufacture of the $\mathrm{H}-327$ reference core. The design of the $\mathrm{H}-451$ elements is identical to that of the $\mathrm{H}-327$ elements in the reference core. No changes are required to the plant Technical Specifications, and there are no unreviewed safety questions per 10CFR50.59.

This report shows that $\mathrm{H}-451$ graphite is a better structural material than $\mathrm{H}-327$ graphite owing to its near-isotropic nature, its lower irradiation-induced axial dimensional changes, and its higher strength. The use of $\mathrm{H}-451$ graphite results in negligible changes in the nuclear or thermal behavior of the core and does not result in reduced safety margins or reliability compared to the reference $\mathrm{H}-327$ core.

This report is divided into three major sections: (1) a performance analysis of the $\mathrm{H}-451$ elements, encompassing the nuclear, thermal, and structural design; (2) a safety analysis of the effect of the $\mathrm{H}-451$ elements on accidents considered in the FSAR, and (3) a summary of materials property data for H-451 graphite. 
GLP-5588

In this document, the "reference core" is defined as the standard design FSV core operating with its initial H-327 graphite elements. 


\section{PERFORMANCE ANALYSIS}

\subsection{CORE NUCLEAR ANALYSIS}

The only change in the core nuclear design resulting from the adoption of H-451 graphite is an approximate $2 \%$ decrease in the core average carbon concentration at equilibrium. This is due to the slightly lower density of H-451 graphite and requires some minor modifications to the design of reload segments as described below. There is no effect on the safety analyses presented in the FSAR, and no changes in Technical Specifications are required by the change to $\mathrm{H}-451$ graphite for FSV fuel and reflector elements.

\subsubsection{Fuel Loading and Excess Reactivity}

The decrease in moderator density hardens the neutron energy spectrum and decreases reactivity. This reactivity loss can be essentially eliminated by maintaining a constant $\mathrm{C} / \mathrm{Th}$ ratio in each reload segment. A decrease in thorium load requires a slight increase in uranium load. However, the change in $\mathrm{C} / \mathrm{U}$ ratio is negligible (less than $0.5 \%$ ) and the excess reactivity of the core will remain within FSAR values.

\subsubsection{Power Distribution}

Since the change in carbon density is uniform in the radial and axial directions and since the thorium and uranium segment loads change only slightly, the region peaking factors (RPFs) and the axial power profiles are expected to be the same regardless of the graphite type used. Due to the slight hardening of the flux spectrum, the worth of thermal neutrons leaking into the core from reflectors will increase somewhat, resulting in $22 \%$ increase in local power peaking at the core edge. These power peaks will be controlled, if necessary, by appropriate fuel zoning. 
GLP -5588

\subsubsection{Fuel Burnup and Exposure}

There will be no change in particle burnup. The fast flux

(E $\geq 29 \mathrm{fJ})_{\text {HTGR }}$ will increase by $\sim 2 \%$ with a corresponding increase in the fast flux exposure of fuel elements.

\subsubsection{Shutdown Margins and Reactor Contro1}

About $50 \%$ of the absorptions in control rods occur in the fast and epithermal energy ranges $(E>380 \mathrm{fJ})_{\mathrm{HTGR}}$. The reduction in both thorium and carbon concentration will tend to increase the migration length, which increases the effectiveness of the control rods. The control rod bank worth is expected to increase by $0.003 \Delta \mathrm{k}$. The worth of the maximum worth rod pair in a fully rodded core will increase by $0.0015 \Delta \mathrm{k}$; that is, the shutdown margins will increase slightly and the safety of the reactor will be enhanced.

\subsubsection{Rod Withdrawal Accidents (RWAs)}

The increase in the maximum worth rod pair during power operation is expected to be small. For each reload cycle, it will be shown that the consequences of an RWA during that cycle are no worse than for the postulated RWA described in the FSAR, i.e., the withdrawal of $0.012 \Delta \mathrm{k}$ at the end of cycle of the equilibrium core. The change to $\mathrm{H}-451$ graphite will not result in the consequences of the postulated RWA exceeding those presented in the FSAR.

\subsection{CORE THERMAL ANALYSIS}

The core thermal analysis presented in Section 3.6 of the FSAR will be affected by a change to H-451 graphite because of its thermal conductivity. The available data (see Section 4.1) indicate that the thermal conductivity of H-451 graphite is approximately a factor of 1.2 greater than that of H-327 graphite. The increased thermal conductivity will result in a 
smaller temperature rise across the graphite web and in lower fuel centerline temperatures.

For example, Fig. 3.6-2 of the FSAR presented a temperature distribution in a typical fuel element at the core axial midplane. The temperature rise across the graphite web was about $90^{\circ} \mathrm{F}$. With an increase by a factor of 1.2 in graphite thermal conductivity, this temperature rise, and hence the fuel centerline temperature, will be reduced by about $15^{\circ} \mathrm{F}$.

Reductions in fuel temperatures will lead to lower kernel migration rates and a resulting increased margin relative to the core thermal safety limit.

\subsection{FISSION PRODUCT TRANSPORT ANALYSIS}

The release of noble gas and gas-like ( $\mathrm{Se}, \mathrm{Te}, \mathrm{I}$ ) fission products is expected to be reduced with the use of $\mathrm{H}-451$ graphite in the core. The reduction in gaseous fission product release will result from the lowering of the fuel temperature discussed in Section 2.2 and its effects on $R / B$, the gaseous fission product release-to-birth rate ratio in the fuel.

Negligible changes in the release of metallic fission products are expected due to decreases in fuel temperature. The available data indicate that the sorptivity and diffusivity of elements such as strontium are the same for both $\mathrm{H}-327$ and H-451 graphites (Refs. 2-1 through 2-4). Hence, changes in graphite type will not affect the release of metallic fission products.

Therefore, the circulating and plateout activity source terms presented in Tables 3.7-1 and 3.7-2 of the FSAR remain conservative with $\mathrm{H}-451$ graphite replacing $\mathrm{H}-327$ graphite in the FSV core. 
GLP-5588

\subsection{GRAPHITE STRUCTURAL ANALYSIS}

\subsubsection{Mechanical Properties}

The mechanical properties of the $\mathrm{H}-451$ graphite fuel and reflector elements will differ from those of the $\mathrm{H}-327$ elements in the reference core due primarily to the use of a near-isotropic petroleum-coke filler material. The design advantages of $\mathrm{H}-451$ graphite over $\mathrm{H}-327$ can be attributed to use of this filler material rather than the needle-coke filler used in $\mathrm{H}-327$. The mechanical properties that determine the element stresses, stressstrength margins, and element deformations for the two types of graphites are discussed below.

2.4.1.1. Elastic Modulus. The axial modulus of $\mathrm{H}-451$ graphite is typically lower than that of $\mathrm{H}-327$ graphite at a11 fluence levels and therefore, for a given strain, the axial stresses in $\mathrm{H}-451$ graphite elements are lower than those in $\mathrm{H}-327$ graphite elements. The radial modulus of $\mathrm{H}-451$ graphite is higher than that of $\mathrm{H}-327$, but its effect on $\mathrm{H}-451$ stress is compensated for by the higher radial strength of $\mathrm{H}-451$ graphite.

2.4.1.2. Tensile Strength. The tensile strengths for $H-451$ graphite are given in Section 4.1.4, Table 4-2, and the tensile strengths for $\mathrm{H}-327$ graphite are given in Section 4.2.4, Table 4-8. It can be seen that the strength of $\mathrm{H}-451$ graphite in both the radial and axial directions is higher than that of $\mathrm{H}-327$ graphite.

2.4.1.3. Creep Properties. The steady-state creep behavior of both graphites is similar, with $\mathrm{H}-451$ having slightly lower values of creep strain.

2.4.1.4. Irradiation-Induced Dimensional Change. Operating stresses are produced within the graphite elements by strains due to differential . irradiation-induced dimensional changes across the element. The irradiation-induced dimensional changes of H-451 graphite in both the axial and radial directions are shown in Section 4.1.3, Figs. 4-1 and 4-2. 
The irradiation-induced dimensional changes for $\mathrm{H}-327$ graphite are shown in Section 4.2.3, Fig. 4-5. A comparison of these two graphites shows that at peak temperatures and fluences the irradiation-induced dimensional change of H-451 graphite in the axial direction is about $50 \%$ lower than that of H-327 graphite. Therefore, at a given temperature and fluence, axial stresses caused by dimensional change in the elements made from $\mathrm{H}-451$ graphite are lower than those in the H-327 graphite elements they replace.

2.4.1.5. Thermal Strains. While the irradiation-induced strains make the major contributions to the operating stresses within the graphite elements, the thermal strains contribute strongly to the shutdown stresses. The thermal expansion of $\mathrm{H}-451$ graphite is about $30 \%$ and $100 \%$ higher than that of H-327 graphite in the radial and axial directions, respectively, for all temperatures of interest.

2.4.1.6. Thermal Conductivity. This property determines the temperature distribution in the graphite elements. The thermal conductivity of $\mathrm{H}-451$ graphite is greater than that of $\mathrm{H}-327$ graphite. This tends to reduce operating and shutdown stresses in the $\mathrm{H}-451$ graphite because of the smaller temperature differentials as compared with those for H-327 graphite.

\subsubsection{Stress Analysis}

The computer programs FESIC and SAFE GRAPHITE were used to calculate the operating and shutdown strain and stress distributions, both axially and radially. These are the same methods that were used to determine the fuel element stresses and strains presented in the FSAR. Maximum stresses and deformations were determined for both the H-327 graphite and H-451 graphite elements using initial core operating conditions. Materials property data used in these analyses are given in Section 4 for both $\mathrm{H}-327$ and $\mathrm{H}-451$ graphite.

The initial thermal stresses produce a compressive stress near the fuel channel and a tensile stress near the coolant channel. The maximum calculated $\mathrm{H}-451$ element initial thermal tensile stresses were $710 \mathrm{kPa}$ 
(103 psi) in the axial direction and $648 \mathrm{kPa}(94 \mathrm{psi}$ ) in the radial direction. This compares with maximum initial core $\mathrm{H}-327$ stresses of $724 \mathrm{kPa}$ (105 psi) and $282 \mathrm{kPa}$ (41 psi) for the axial and radial orientations, respectively.

Although the H-451 fuel element has slightly higher stress levels than the H-327 element, it provides a higher design margin (the difference between strength and stress) due to its greater strength. Using mean strength values from the conservative midlength center $10 \mathrm{~g}$ positions listed in Table 4-2 (Section 4.1.4) and Table 4-8 (Section 4.2.4), the design margins for the axial and radial directions are shown to be 12,872 $\mathrm{kPa}(1,867 \mathrm{psi})$ and $10,108 \mathrm{kPa}(1,466 \mathrm{psi})$ for $\mathrm{H}-451$ graphite and 10,514 $\mathrm{kPa}$ $(1,525 \mathrm{psi})$ and $6,198 \mathrm{kPa}(899 \mathrm{psi})$ for $\mathrm{H}-327$ graphite elements.

As shown in Figs. 4-1 and 4-2 of Section 4.1, under irradiation by fast neutrons, the hotter graphite shrinks faster than the cooler graphite. After a period of operation varying from a few months to about a year, the irradiation-induced dimensional changes overcome the thermal strains in magnitude, and the cooler portion of the graphite which was originally in tension goes into compression while the hotter portion goes into tension.

The FSV plant is expected to operate continuously between refueling operations. However, shutdowns can occur at any time. These shutdowns cause large changes in temperature distributions and the resulting elastic stresses in the fuel elements. In the absence of creep and irradiation strain, a shutdown to a state of uniform temperature would simply remove the operating thermal stress and reduce the stress to zero. The influence of creep and irradiation strain, however, causes maximum shutdown stresses higher than maximum normal operating stresses.

Shutdown stresses are calculated periodically for the elements by superimposing a shutdown on the normal continuous operating history. The maximum calculated shutdown tensile stresses for the H-451 fuel elements were $958 \mathrm{kPa}$ (139 psi) and $1,276 \mathrm{kPa}$ (185 psi) for the axial and radial orientations, respectively. This compares with maximum initial H-327 'core 
stresses of $1,634 \mathrm{kPa}(237 \mathrm{psi})$ and $724 \mathrm{kPa}(105 \mathrm{psi})$ in the axial and radial orientations, respectively.

The design margins for the axial and radial orientations are $12,624 \mathrm{kPa}(1,831 \mathrm{psi})$ and $9,480 \mathrm{kPa}(1,375 \mathrm{psi})$ for $\mathrm{H}-451$ and $9,605 \mathrm{kPa}$ $(1,393 \mathrm{psi})$ and $5,757 \mathrm{kPa}(835 \mathrm{psi})$ for the H-327 graphite fuel elements.

A summary of operating and shutdown stresses is given in Table 2-1.

Based on the above analysis, it is concluded that the inclusion of the $\mathrm{H}-451$ graphite elements in the FSV reactor will improve the stress margins relative to those of the reference core. Because of the improved stress margins, the $\mathrm{H}-451$ elements will have a larger design margin for a given seismic load than the $\mathrm{H}-327$ elements that they replace.

\subsubsection{Graphite Dimensional Change}

During core operation, the graphite fuel elements will be exposed to fast neutron irradiation which will induce dimensional changes. Because of the differences in dimensional change behavior between $\mathrm{H}-451$ and $\mathrm{H}-327$ graphite, an analysis was performed to calculate the expected axial and radial dimensional changes of the elements. As illustrated by the dimensional change curves (Sections 4.1 and 4.2 ), the maximum axial shrinkages of the H-451 element are less than those of the corresponding $\mathrm{H}-327$ elements for all fluence levels. The maximum calculated axial shrinkage for the H-451 elements was $1.3 \%$ while the H-327 fuel elements exhibited a maximum of $2.2 \%$ axial shrinkage. For the radial direction, the maximum calculated end-of-life shrinkage for the $\mathrm{H}-451$ elements is $0.66 \%$ compared with the $0.56 \%$ calculated for the initial core $\mathrm{H}-327$ fuel elements.

The maximum bowing in the fuel elements will occur in a buffer location, adjacent to the side reflector. This bowing is primarily caused by the large radial fast neutron flux gradient across the fuel element. The maximum calculated end-of-life bowing for the $\mathrm{H}-451$ fuel elements is about $0.147 \mathrm{~cm}$ (0.058 in.) (maximum difference between bowed and original axial 
GLP-5588

centerlines) as compared with the $0.142 \mathrm{~cm}(0.056 \mathrm{in.})$ maximum bowing predicted for the reference $\mathrm{H}-327$ elements. Therefore, column tilting and the resulting element interface coolant flow will not be significantly affected.

Since the radial shrinkage and bowing are similar for $\mathrm{H}-451$ and $\mathrm{H}-327$ fuel elements, no compatibility problems are expected during the transition period when the core will contain both H-327 and H-451 elements. However, the differences in axial shrinkage will require that any given axial layer in a region be composed of the same type of graphite.

\section{REFERENCES}

2-1. "HTGR Base Program Quarterly Report for the Period Ending May 30, 1969," USAEC Report GA-8372, Gulf General Atomic, June 27, 1969, pp. $135-139$.

2-2. "HTGR Base Program Quarterly Report for the Period Ending August 31, 1970," USAEC Report GA-10288, Gulf General Atomic, September 30, 1970, pp. 10-12.

2-3. "HTGR Fuels and Core Development Quarterly Progress Report for the Period Ending November 30, 1974," USAEC Report GA-A13253, Genera1 Atomic Company, January 31, 1975, pp. 7-8.

2-4. Myers, B. V., and W. E. Be11, "Strontium Transport Data for HTGR Systems," USAEC Report GA-A13168, General Atomic Company, December 6, 1974 , p. 5-12 and p. 6-13. 
TABLE 2-1

COMPARISON OF MAXIMUM INITIAL OPERATING AND SHUTDOWN TENSILE STRESSES IN THE H-451 AND H-327 FUEL ELEMENTS IN THE ORIGINAL CORE

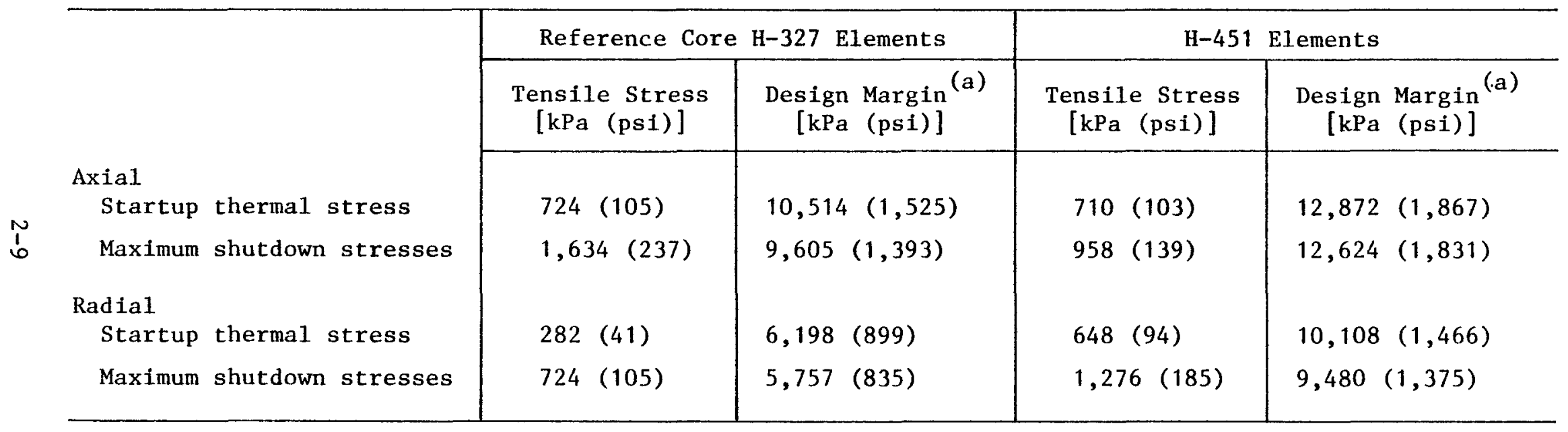

(a) Design margin is defined as the strength of the graphite from the minimum strength, midlength center position of the fuel element minus the stress at the area of concern. 


\section{SAFETY ANALYSIS}

\subsection{INTRODUCTION AND SUMMARY}

In this section, events and accidents previously analyzed in Chapter XIV of the Fort St. Vrain FSAR are reviewed to determine if the substitution of H-451 graphite in FSV reload cores could alter the consequences of postulated accidents. The purpose of such a review is to assure that:

1. The worst case conditions previously defined for accident analyses, and found to be acceptable during the FSAR review, are not exceeded as a consequence of introducing $\mathrm{H}-451$ graphite into the core.

2. The recent submittal (Ref, 3-1) to the NRC, which updates certain FSAR analyses, will not be invalidated.

Chapter XIV of the FSAR has been examined to identify those events which might be affected by the insertion of fuel elements of H-451 graphite into the core. The results of this examination are given in Table 3-1. Those events which require a more detailed examination are:

1. Rod withdrawal accidents (RWAs).

2. Fuel element malfunctions.

3. Loss of normal shutdown cooling (limiting case: cooldown on one firewater-driven circulator).

4. Moisture inleakage. 
GLP-5588

5. Permanent loss of forced circulation.

6. Rapid depressurization/blowdown.

As indicated in Table 3-1, RWAs and fuel element malfunctions are discussed in Sections 2.1 and 2.4 of this document, respectively.

In the sections which follow, it is demonstrated for the remaining events (i.e., items 3 through 6 ) that existing FSAR results of accident analyses conservatively bound any perturbations resulting from the introduction of H-451 graphite fuel elements.

\subsection{LOSS OF NORMAL SHUTDOWN COOLING}

Loss of normal shutdown cooling is discussed in Section 14.4 of the FSAR. The limiting case (Section 14.4.2.1, Case B2) of this event is cooling with one circulator driven by the firewater system.

A recent submittal (Ref. 3-1) indicates that peak fuel temperature during a firewater cooldown can be significantly reduced if booster pumps are added to the system. Firewater booster pump(s) will be installed prior to restart following the first refueling. This change will permit safe operation at full power for all reload cycles at Technical Specification limits for core region outlet temperature dispersion and region peaking factors for either graphite material.

\subsection{MOISTURE INLEAKAGE}

The analysis in Section 14.5 .2 of the FSAR considers inleakage into the primary coolant system from an economizer-evaporator-superheater subheader or tube or from the helium circulator bearing water supply.

of the moisture ingress cases treated in the FSAR, Case 5, a steam generator subheader rupture compounded by concurrent failure of the moisture monitor system and dumping of the wrong (non-leaking) steam loop, has 
the greatest potential for graphite oxidation and fuel hydrolysis in the shortest time following the accident. As shown in the FSAR, Cases 5 and 6 actually show comparable results. To evaluate the potential effect of the application of H-451 graphite on the analysis of Case 5, the following phenomena were investigated:

1. Steam-graphite reaction.

2. Hydrolysis of failed fuel.

3. Potential change in fission product release due to (1) and (2).

\subsubsection{Steam-Graphite Reactions}

As shown in Figs. 6-1 and 6-2 of Ref. 3-2, the steam-graphite reaction rates at various temperatures for $\mathrm{H}-327$ and $\mathrm{H}-451$ are approximately equal within experimental uncertainty over the temperature range of interest $\left[700^{\circ}\right.$ to $1300^{\circ} \mathrm{C}\left(1292^{\circ}\right.$ to $\left.\left.2372^{\circ} \mathrm{F}\right)\right]$. Furthermore, the reaction dependence on fractional grpahite burnoff is not particularly sensitive to the change in graphite type. Hence, the same reaction rate equations have been recommended for both types of graphite.

Since the thermal conductivity of $\mathrm{H}-451$ is somewhat higher than that of H-327, graphite temperatures will be somewhat lower tending to reduce reaction rates. In addition, as long as reload segments contain reference fue1, catalyst (barium and strontium) concentrations in the fuel blocks will remain within the conservative values already used to calculate the effect of these catalysts. Thus, for a given inleakage of steam or water into the primary coolant system, the amount of core graphite which reacts will be approximately the same for either type of graphite. Accordingly, the production of $\mathrm{CO}$ and $\mathrm{H}_{2}$ during the moisture ingress events will be approximate1y the same and, thus, primary coolant system pressure rise during moisture ingress will also be approximately equal for either graphite. 


\subsubsection{Hydrolysis of Failed Fuel}

Hydrolysis of failed fuel can result in the release of a small fraction of the noble gas fission product inventory from the core to the primary coolant system. However, since the primary coolant system remains essentially leak tight after a steam leak accident, this release represents no hazard to the general public.

The hydrolysis reaction with fuel particles occurs only when steam diffuses through the graphite block and reacts with fuel kernels having coatings that failed prior to the moisture ingress event. The rate of hydrolysis and associated release of noble gas fission products is dependent upon local fuel temperatures and steam concentration.

As noted in Section 2.2, the increased thermal conductivity of $\mathrm{H}-451$ will result in somewhat lower fuel temperatures. Thus, the magnitude of fuel coating failures considered in the FSAR for moisture ingress events should conservatively bound those estimates after the substitution of $\mathrm{H}-451$ graphite.

The slightly lower fuel element graphite temperatures will have only a small effect on the graphite reaction and corresponding depletion of steam concentration; thus, the extent of the fuel hydrolysis reaction during moisture ingress events is expected to be nearly the same for $\mathrm{H}-451$ graphite as that predicted for the $\mathrm{H}-327$ graphite.

\subsubsection{Fission Product Release from Oxidized Graphite}

The amount of activity released to the primary coolant system from oxidized graphite is proportional to the amount of graphite reacted and the concentration of fission products within that graphite. The fission product retention characteristics of $\mathrm{H}-451$ graphite are similar to $\mathrm{H}-327$ and since no change in fuel failure characteristics is anticipated, the fission product concentration in the fuel blocks will be essentially unchanged after the substitution of $\mathrm{H}-451$. 
Thus, since the amount of graphite reacted is approximately the same for either type, the corresponding release of fission products will also be the same.

3.4. PERMANENT LOSS OF FORCED COOLING [DESIGN BASIS ACCIDENT NO. 1 $(\mathrm{DBA}-1)]$

This hypothetical event assumes permanent loss of forced circulation of primary coolant helium. The FSAR considers consequences of this event in four categories:

1. Thermal results wherein metallic components might fail.

2. Structural results which might affect the core, reflector, barrel, or core support.

3. Nuclear consequences which affect shutdown capability.

4. Fission product release and offsite doses.

The substitution of H-451 graphite will not alter the thermal effects significantly and the conclusion in the FSAR will remain unchanged.

The structural results mainly concern thermal stresses which might affect the structural integrity of the core support and lateral restraint. Such structural effects, external to the core, are not influenced by the nature of the fuel element graphite. In addition, there is little concern regarding the fuel blocks and reflector because the maximum compressive load in these components at the bottom of the core is less than $140 \mathrm{kPa}$ (20 psi) (about half that at the hottest central core region). These loads are small compared with the graphite axial compressive stress. In addition, the strength of H-451 graphite is superior to that of $\mathrm{H}-327$ (see Section 2.4). 
The nuclear consequences concern reactivity effects whereby the potential reduction of shutdown margin in the overheated core could result from compaction and melting of control rods or spatial redistribution of control poison, fission product poisons, or uranium and thorium. The FSAR shows that these effects do not result in an increase in reactivity at any time during the accident. Since no change in fuel is being considered, the core is expected to perform quite similarly to the existing core with respect to fission product and fuel redistribution during a loss of forced cooling (LOFC) event. As noted in Section 2.1, the presence of H-451 graphite in the core will not have a significant effect on reactivity.

The offsite doses for DBA-1, reported in Table 14.10-1 of the FSAR, are small fractions of the 10CFR100 guidelines even with the conservative assumption of TID-14844 release fractions. Because the fission product retention capabilities are similar to those for $\mathrm{H}-327$, the substitution of H-451 graphite will have a negligible effect on the fission product release characteristics during the core heatup event and, hence, the FSAR conclusion regarding the event remains unchanged.

\subsection{RAPID DEPRESSURIZATION/BLOWDOWN (DBA-2)}

The FSAR considers three classes of events for loss of primary coolant: primary coolant leakage (Section 14.7), maximum credible accident (Section 14.8), and the hypothetical DBA-2, "rapid depressurization/blowdown"

(Section 14.11). Since the third class envelopes any potential consequences of the other two, it alone was considered for possible impact by the H-451 graphite.

The aspects of a DBA-2 which are discussed in Section 14.11 of the FSAR are as follows:

1. Integrity of reactor internals.

2. Continuation of adequate primary coolant circulation.

3. Ingress of air.

4. Effects of operator actions. 
5. Vertical thrust on the PCRV.

6. Effect on building pressure.

7. Radiological consequences.

Item 1 concerns the pressure differentials that could develop across reactor components during the depressurization. Item 2 concerns the ability of the helium circulators to continue operation and provide adequate core cooling in the event of a PCRV penetration failure. These items obviously are not affected by the presence of H-451 graphite in the core except for the fact that $\mathrm{H}-451$ has higher strength and therefore has greater margins of safety under accident loadings.

Item 3 concerns the possible pathways for air ingress into the PCRV following a DBA-2. The FSAR shows that the operation of a helium purge flow would virtually exclude oxygen from entering the PCRV and that even if the purge were inoperative, the oxygen ingress would be insignificant with respect to heat generation and graphite combustion. Since the mechanical design of the PCRV and purge system is not being altered and the oxidation reaction rate with air is rapid and insensitive to catalytic effects and the type of graphite, the FSAR conclusions are not altered.

Regarding item 4, the FSAR describes how automatic reactor scram and alarm would alert the operator to the fact that a leak has developed in the PCRV and to be ready to perform necessary monitoring and system adjustments. The operator's responsibilities are neither increased nor diminished by the presence of $\mathrm{H}-451$ graphite in the core. Items 5 and 6 concern mechanical processes external to the PCRV and core. Therefore, only item 7 needs to be examined in further detail.

As discussed in the FSAR, the radiological release from a postulated DBA-2 consists of essentially all the activity which exists in the circulating primary coolant prior to the depressurization event plus a small fraction of the activity plated out on the surfaces of the primary circuit. Since the fission product transport and retention characteristics of the H-451 graphite are nearly identical to those of $\mathrm{H}-327$, the radiological 
GLP -5588

consequences of this accident would be essentially unchanged from those reported in the FSAR.

\subsection{CONCLUSIONS}

A review of Chapter XIV of the FSAR identified six postulated accident conditions which required more detailed examiniation for potential impact from the substitution of $\mathrm{H}-451$ graphite for the fuel element block material. These accident conditions were discussed in this section and no requirement for additional analysis has been identified. It is concluded that:

1. The worst case conditions previously defined for accident analyses, and found to be acceptable during the FSAR review, are not exceeded as a result of introducing $\mathrm{H}-451$ graphite.

2. Reference 3-1, which updates certain FSAR analyses, will not be invalidated by the introduction of $\mathrm{H}-451$ graphite as the fuel element block material.

\section{REFERENCES}

3-1. Fuller, J. K., Public Service Company of Colorado, to R. P. Denise, NRC, P-77221, dated November 1, 1977, Subject: Technica1 Specifications 4.1 .3 and 4.1 .7 .

3-2. Engle, G. B., et al, "Development Status of Near-Isotropic Graphites for Large HTGRs", USAEC Report GA-A12944, General Atomic Company, June 1, 1974. 
TABLE 3-1

POTENTIAL EFFECTS OF H-451 GRAPHITE ON FSV FSAR ACCIDENT PREDICTIONS

\begin{tabular}{|c|c|c|}
\hline & FSAR Chapter XIV Event & $\begin{array}{l}\text { Potential Effects on Event Analysis Due } \\
\text { to Application of } \mathrm{H}-451 \text { Graphite }\end{array}$ \\
\hline 14.1 & $\begin{array}{l}\text { Wind effects } \\
\text { Flood } \\
\text { Fire } \\
\text { Landslides } \\
\text { Snow and ice }\end{array}$ & $\begin{array}{l}\text { Mechanical effects are discussed in Section } 2.4 \text {. } \\
\text { Any reactivity effect would be bounded by rod } \\
\text { withdrawal events. } \\
\text { The core is not affected by these events. }\end{array}$ \\
\hline 14.2 & $\begin{array}{l}\text { Reactivity Accidents and Transient Response } \\
\text { Summary of reactivity sources } \\
\text { Excessive removal of control poison } \\
\text { Loss of fission product poisons } \\
\text { Rearrangement of core components } \\
\text { Introduction of steam into core } \\
\text { Sudden decrease in reactor temperature } \\
\text { Rod withdrawal accidents }\end{array}$ & $\begin{array}{l}\text { Reactivity insertions in these events are less than } \\
\text { rod withdrawal events. } \\
\text { Evaluation required, see Section } 2.1 \text { of this document. }\end{array}$ \\
\hline 14.3 & $\begin{array}{l}\text { Incidents } \\
\text { Incidents Involving the Reactor Core } \\
\text { Column deflection and misalignment } \\
\text { Fuel element malfunctions } \\
\text { Misplaced fuel element } \\
\text { Blocking of coolant channel } \\
\text { Control rod malfunctions } \\
\text { Orifice malfunctions } \\
\text { Core support floor loss of cooling } \\
\text { Incidents involving the primary coolant system } \\
\text { Incidents involving the control and instru- } \\
\text { mentation system } \\
\text { Incidents involving the PCRV }\end{array}$ & $\begin{array}{l}\text { No change from Section } 3.3 .1 .2 \text { of FSAR. } \\
\text { Evaluation required, see Section } 2.4 \text { of this document. } \\
\text { No change from Section } 3.5 .4 .5 \text { of FSAR. } \\
\text { No change from Section } 3.6 .5 .2 \text { of FSAR. } \\
\text { No change from Section } 3.8 \text { of FSAR. } \\
\text { No change from Section } 3.6 .5 .1 \text { of FSAR. } \\
\text { No change from Section } 3.3 .2 .2 \text { of FSAR. } \\
\text { None } \\
\text { None } \\
\text { None }\end{array}$ \\
\hline
\end{tabular}


Tab1e 3-1 (Continued)

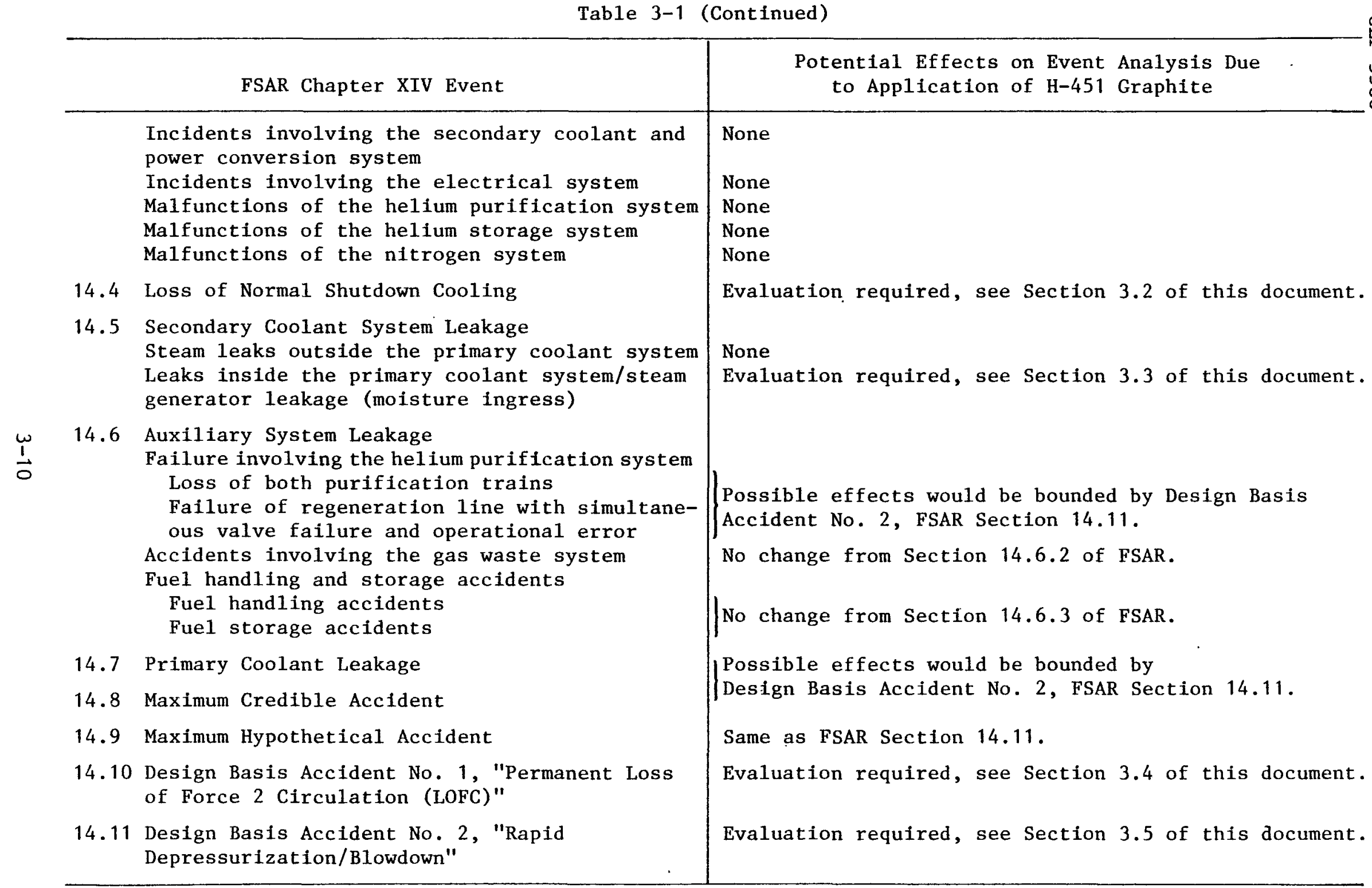




\section{MATERIALS PROPERTY DATA}

Determination of the material properties of nuclear-grade graphite is a continuing program at General Atomic Company. The most recent values of H-451. and H-327 graphite material properties were used in the analyses prepared for this report and are given in Sections 4.1 and 4.2 , respectively.

\subsection{H-451 GRAPHITE MATERIALS PROPERTY DATA}

\subsubsection{Specific Heat}

The specific heat of $\mathrm{H}-451$ graphite over the temperature range $0^{\circ}$ to $2700^{\circ} \mathrm{C}$ is given by Eq. $4-1$, which is accurate to $\pm 5 \%$ of the mean (Ref. 4-1):

$$
\begin{aligned}
C_{P}= & 0.54212-2.42667 \times 10^{-6} \mathrm{~T}-90.2725 \mathrm{~T}^{-1} \\
& -4.34493 \times 10^{4} \mathrm{~T}^{-2}+1.59309 \times 10^{7} \mathrm{~T}^{-3} \\
& -1.43688 \times 10^{9} \mathrm{~T}^{-4} .
\end{aligned}
$$

\subsubsection{Bulk Density}

The mean bulk density for the $\mathrm{H}-451 \log$ is $1.74 \mathrm{Mg} / \mathrm{m}^{3}$ (Ref. 4-2).

\subsubsection{Irradiation-Induced Dimensional Change (Ref. 4-3)}

The permanent strain $\left(\varepsilon^{\circ}\right)$ due to irradiation-induced dimensional change has been expressed in terms of average irradiation temperature $\left(\mathrm{T}_{\phi}\right)$ and fast neutron fluence $(\Phi)$ for near-isotropic graphite. The irradiation strain $\left(\varepsilon^{\circ}\right)$ is expressed by the polynomial in Eq. 4-2, which is valid for 
GLP -5588

irradiations between $300^{\circ}$ and $1500^{\circ} \mathrm{C}$ and to fast neutron fluences of $8 \times 10^{25} \mathrm{n} / \mathrm{m}^{2}(\mathrm{E} \geq 29 \mathrm{fJ})_{\mathrm{HTGR}}$ :

$$
\begin{aligned}
\varepsilon^{\circ}= & \left(C_{1}=C_{2} T_{\phi}+C_{3} T_{\phi}^{2}+C_{4} T_{\phi}^{3}+C_{5} T_{\phi}^{4}\right) \Phi \\
& +\left(C_{6}+C_{7} T_{\phi}+C_{8} T_{\phi}^{2}+C_{9} T_{\phi}^{3}+C_{10} T_{\phi}^{4}\right) \Phi^{2} \\
& +\left(C_{11}+C_{12} T_{\phi}+C_{13} T_{\phi}^{2}+C_{14} T_{\phi}^{3}+C_{15} T_{\phi}^{4}\right) \Phi^{3},
\end{aligned}
$$

where $\varepsilon^{\circ}=$ irradiation-induced strain (dimensional change, $\Delta \ell / \ell$ ) $(\%)$,

$\Phi=$ HTGR fast neutron fluence $\left(10^{25} \mathrm{n} / \mathrm{m}^{2}\right)(\mathrm{E} \geq 29 \mathrm{fJ})_{\mathrm{HTGR}}$,

$\mathrm{T}_{\phi}=$ average irradiation temperature $\left({ }^{\circ} \mathrm{C}\right)$,

$C_{i}=$ coefficients determined for each orientation of H-451 graphite; coefficients listed in Table 4-1.

The curves generated by the polynomial (Eq. 4-2) are presented graphically in Figs. 4-1 and 4-2.

\subsubsection{Ultimate Tensile Strength}

The ultimate tensile strength (UTS) of unirradiated $\mathrm{H}-451$ graphite is determined for the conservative midlength center position of the graphite log, as given in Table 4-2.

\subsubsection{U1timate Compressive Strength (Ref. 4-4)}

The ultimate compressive strength (UCS) is $\geq 48,263 \mathrm{kPa}$ (7000 psi) for both the axial and radial directions.

\subsubsection{Elastic Modulus}

The elastic modulus of unirradiated $\mathrm{H}-451$ graphite is given in Table 4-3 for the midlength center position of the graphite $\log$. 


\subsubsection{Poisson's Ratio}

The Poisson's ratio $(\nu)$ for $H-451$ graphite subjected to tensile strain is given as (Ref. 4-4)

$$
v=0.118( \pm 0.01) \text {. }
$$

\subsubsection{Irradiation Creep Behavior}

Irradiation-induced creep for both tensile and compressive stresses in near-isotropic graphite is described by Eq. 4-3 (Ref. 4-5):

$$
\begin{aligned}
\varepsilon_{c r}= & 0.91 \times 10^{-6} \sigma\left[1-\exp \left(-5 \times 10^{-20} \Phi\right)\right] \exp \left(1.72 \times 10^{-3} \mathrm{~T}-0.83\right) \\
& +10^{-27} \sigma \Phi \exp \left(0.321+7.48 \times 10^{-4} \mathrm{~T}\right),
\end{aligned}
$$

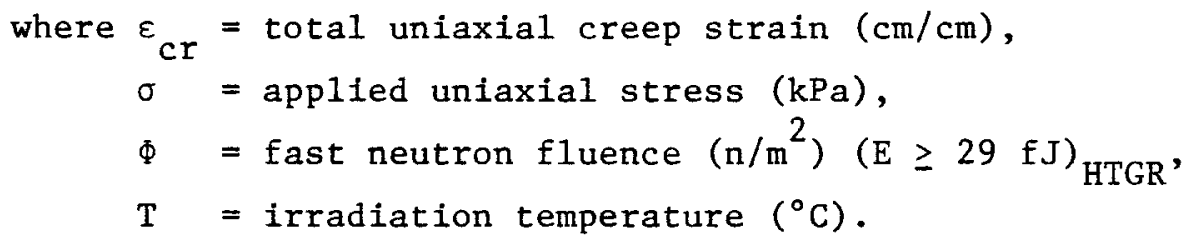

Equation 4-3 is valid for tensile and compressive stresses at irradiation temperatures between $500^{\circ}$ and $1200^{\circ} \mathrm{C}$, fast neutron fluences up to $10^{26} \mathrm{n} / \mathrm{m}^{2}$, and creep strain up to $2.5 \times 10^{-2} \mathrm{~cm} / \mathrm{cm}$ in tension and $2 \times 10^{-2} \mathrm{~cm} / \mathrm{cm}$ in compression. The steady-state creep strain (1ine 2 of Eq. 4-3) is a true plastic strain, whereas the transient creep strain is quasi-elastic and is recovered over an interval of $\sim 2 \times 10^{23} \mathrm{n} / \mathrm{m}^{2}$ if the stress is reduced during irradiation.

\subsubsection{Thermal Expansion}

Figure 4-3 presents the design curve of thermal strain versus temperature for near-isotropic H-451 graphite. Figure 4-3 is presented in tabular form in Table 4-4. 
GLP-5588

\subsubsection{Thermal Conductivity}

The thermal conductivity of near-isotropic graphite is given by the model of R. Price (Ref. 4-6). This model considers the dependence of thermal conductivity $(K)$ on the current measurement of temperature $\left(T_{c}\right)$ and on the past history of irradiation temperature $\left(\mathrm{T}_{1}\right)$ and fast neutron fluence $(\Phi)$. The model is extended here to the case of a nonisothermal irradiation with unknown temperatures.

The thermal conductivity as a function of current measurement temperature can be considered as a superposition of three temperature-dependent resistance mechanisms through the equation

$$
K\left(T_{c}\right)=\frac{1}{\alpha\left[\frac{1}{K_{U}\left(T_{c}\right)}+\frac{b}{K_{b}^{\prime}\left(T_{c}\right)}+\frac{d}{K_{D}^{\prime}\left(T_{c}\right)}\right]} \text {, }
$$

\footnotetext{
where $\alpha$ is a porosity-tortuosity factor,

$\mathrm{K}_{U}\left(\mathrm{~T}_{c}\right)$ is the crystallite conductivity with Umklapp processes dominating,

$b \equiv 1 / L_{a}(\operatorname{Ref} .4-6)$ is the inverse of the crystallite boundary spacing,

$\mathrm{K}_{b}^{\prime}\left(\mathrm{T}_{c}\right) \equiv\left(\mathrm{K}_{\mathrm{B}} / \mathrm{L}_{a}\right)\left(\mathrm{T}_{c}\right)(\operatorname{Ref}, 4-6)$ is the effect of the grain boundary scattering,

$\mathrm{d} \equiv \mathrm{C}_{\mathrm{d}} \mathrm{s}_{\mathrm{V}}^{2}$ (Ref. 4-6) is an irradiation damage parameter, $\mathrm{K}_{\mathrm{d}}^{\prime}\left(\mathrm{T}_{\mathrm{c}}\right) \equiv\left(\mathrm{K}_{\mathrm{D}} \mathrm{C}_{\mathrm{D}} \mathrm{S}_{\mathrm{V}}^{2}\right)\left(\mathrm{T}_{\mathrm{C}}\right)($ Ref. $4-6)$ is the effect of the irradiation damage.
}

All of the above quantities are given as known input data in Tables $4-5$ and 4-6 with one exception: the irradiation damage parameter, $d$. As will be shown, one can solve for the parameter d by comparing conductivities before and after irradiation.

4.1.10.1. Thermal Conductivity, Unirradiated. For unirradiated material, the damage parameter $\mathrm{d}$ in Eq. $4-4$ is zero. Equation $4-4$ reduces to 


$$
K_{o}\left(T_{c}\right)=\frac{1}{\alpha\left[\frac{1}{K_{U}\left(T_{c}\right)}+\frac{b}{K_{b}^{\prime}\left(T_{c}\right)}\right]}
$$

A plot of this function is given in Fig. 4-4.

4.1.10.2. Thermal Conductivity, Isothermal Irradiation. The damage parameter $d$ in Eq. 4-4 can be found by comparing the unirradiated and irradiated conductivities at one particular measurement temperature. Room temperature is conveniently taken to be the reference temperature. Thus, Eqs. 4-4 and 4-5 combine to give

$$
d=\frac{K_{d}(R T)}{\alpha}\left[\frac{1}{K_{I}(R T)}-\frac{1}{K_{o}(R T)}\right]
$$

where $\mathrm{K}_{\mathrm{o}}(\mathrm{RT})$ = unirradiated room temperature conductivity, found by evaluating Eq. $4-5$ at $T_{c}=R T$,

$\mathrm{K}_{i}(\mathrm{RT})=$ irradiated room-temperature conductivity found by the procedure outlined below.

4.1.10.3. Thermal Conductivity, Nonisothermal Irradiation. The procedure to be used for calculating room-temperature conductivity during a nonisothermal irradiation is as follows:

1. Divide the irradiation period into $\mathrm{n}$ isothermal intervals. The irradiation temperature during interval $i$ is $T_{i}$. The fluence at the start of the interval is $(\Phi)_{i-1}$, and the fluence at the end of the interval is $(\Phi)_{i}$.

2. At the start of the first interval, the room-temperature conductivity is initialized to $\mathrm{K}_{\mathrm{o}}(\mathrm{RT})$ through $\mathrm{Eq} \cdot$ 4-5.

3. At the end of interval $i$, the room-temperature irradiated conductivity is given by the recursive formula (Eq. 4-7). 
GLP-5588

$$
\begin{aligned}
& K_{i}(R T)= K_{s a t}^{R T}\left(T_{i}\right)+\left[K_{i-1}(R T)-K_{s a t}^{R T}\left(T_{i}\right)\right] \\
& \exp \frac{-\left[(\Phi)_{i}-(\Phi)_{i-1}\right]}{\tau\left(T_{i}\right)}, \\
& \text { where } \tau\left(T_{i}\right)=A+B T_{i}, \\
& K_{\text {sat }}^{R T}\left(T_{i}\right)=\exp \left(C+D T_{i}\right),
\end{aligned}
$$

and where $\Phi=$ fast neutron fluence $\left(10^{25} \mathrm{n} / \mathrm{m}^{2}\right)$

$$
(\mathrm{E} \geq 29 \mathrm{fJ})_{\text {HTGR }}
$$

$\tau=$ relaxation time in units of fluence,

$$
\mathrm{K}_{\text {sat }}^{\mathrm{RT}}=\text { saturation value of the room conductivity, }
$$

$$
A, B, C, D=\text { constants given in Table } 4-6 \text {. }
$$

4. Calculate the conductivity at the assumed current temperature $\mathrm{T}_{\mathrm{c}}$ by applying Eqs. 4-6 and 4-4.

4.1.10.4. Input Data for Near-Isotropic Graphite. The input data required to calculate the thermal conductivity of near-isotropic graphite in the axial and radial directions are given in Tables 4-5 and 4-6.

\subsection{H-327 GRAPHITE MATERIALS PROPERTY DATA}

\subsubsection{Specific Heat}

The specific heat of H-327 graphite at constant pressure is expressed as (Ref. 4-1):

$$
\begin{aligned}
C_{p}= & 0.54212-2.42667 \times 10^{-6} \mathrm{~T}-9.02725 \times 10^{1} \mathrm{~T}^{-1} \\
& -4.34493 \times 10^{4} \mathrm{~T}^{-2}+1.59309 \times 10^{7} \mathrm{~T}^{-3}-1.43688 \times 10^{9} \mathrm{~T}^{-4}(4-10)
\end{aligned}
$$


where $C_{p}=$ specific heat at constant pressure $(\mathrm{cal} / \mathrm{g}-\mathrm{K})$,

$\mathrm{T}$ = temperature $(\mathrm{K})$.

\subsubsection{Bulk Density}

The mean bulk density for the $\mathrm{H}-327 \log$ is $1.77 \mathrm{Mg} / \mathrm{m}^{3}$ (Ref. 4-7).

\subsubsection{Irradiation-Induced Dimensional Change}

The permanent strain $\left(\varepsilon^{\circ}\right)$ due to fast neutron damage in graphite has been measured in many experiments over the past 10 years. The irradiation strain in $\mathrm{H}-327$ graphite is expressed as a polynomial for design use:

$$
\begin{aligned}
\varepsilon^{\circ}= & \left(C_{1}+C_{2} T_{\phi}+C_{3} T_{\phi}^{2}+C_{4} T_{\phi}^{3}+C_{5} T_{\phi}^{4}\right) \Phi \\
& +\left(C_{6}+C_{7} T_{\phi}+C_{8} T_{\phi}^{2}+C_{9} T_{\phi}^{3}+C_{10} T_{\phi}^{4}\right) \Phi^{2} \\
& +\left(C_{11}+C_{12} T_{\phi}+C_{13} T_{\phi}^{2}+C_{14} T_{\phi}^{3}+C_{15} T_{\phi}^{4}\right) \Phi^{3}
\end{aligned}
$$

where $\varepsilon^{\circ}=$ irradiation strain (dimensional change, $\left.\Delta l / \ell\right)(\%)$,

$$
\begin{aligned}
\Phi= & \text { fast neutron fluence }\left(10^{25} \mathrm{n} / \mathrm{m}^{2}\right)(\mathrm{E} \geq 29 \mathrm{fJ})_{\mathrm{HTGR}} \\
\mathrm{T}_{\Phi}= & \text { average irradiation temperature }\left({ }^{\circ} \mathrm{C}\right), \\
\mathrm{C}_{i}= & \text { coefficients determined for each orientation of } \mathrm{H}-327 \text { graphite; } \\
& \text { coefficients listed in Table } 4-7 .
\end{aligned}
$$

The H-327 irradiation strain polynomial is based on data taken from the $O G-1,-2$, and -3 experiments and from earlier capsule experiments which provided design data (Refs. 4-3, 4-8, 4-9). Irradiation strain $\left(\varepsilon^{\circ}\right)$ calculated from the above polynomial is valid for irradiation temperatures from $400^{\circ}$ to $1400^{\circ} \mathrm{C}$ and fast neutron fluences of 0 to $8 \times 10^{25} \mathrm{n} / \mathrm{m}^{2}$ ( $E>29 \mathrm{fJ})_{\text {HTGR }}$. The dimensional change in $\mathrm{H}-327$ is shown in Fig. 4-5. 
GLP -5588

4.2.4. Ultimate Tensile Strength

The ultimate tensile strength of unirradiated $\mathrm{H}-327$ graphite as determined for the conservative midlength center position of the graphite log is given in Table 4-8 (Ref. 4-7).

\subsubsection{U1timate Compressive Strength}

The ultimate compressive strength of $\mathrm{H}-327$ graphite is $\geq 27,579 \mathrm{kPa}$ (4000 psi) (Ref. 4-10).

\subsubsection{Elastic Modulus}

The elastic modulus of unirradiated $\mathrm{H}-327$ graphite is given in Table 4-9 for the midlength center position of the graphite $\log$ (Ref. 4-7).

\subsubsection{Poisson's Ratio}

Poisson's ratio in tension or compression is taken from Ref. 4-11. For a needle-coke graphite $(\mathrm{H}-327)$ stressed along the axial axis, Poisson's ratio $(v)$ is the same in all orthogonal directions:

$$
\nu=0.1 \text { to } 0.15
$$

Poisson's ratio is assumed to be unaffected by irradiation (Ref. 4-11).

\subsubsection{Irradiation-Induced Creep}

Irradiation induced creep strain $\left(\varepsilon_{\mathrm{cr}}\right)$ in H-327 graphite has been discussed by Price (Ref. 4-5). The design equations have been updated to reflect newer modulus values yielding Eqs. 4-12 and 4-13.

$$
\begin{aligned}
\text { Axial } \varepsilon_{c r}= & 0.55 \times 10^{-6} \sigma\left[1-\exp \left(-5 \times 10^{-24} \phi t\right)\right] \exp \left(1.72 \times 10^{-3} \mathrm{~T}\right. \\
& -0.83)+10^{-31} \sigma \phi t \exp \left(1.42 \times 10^{-3} \mathrm{~T}-0.48\right)
\end{aligned}
$$




$$
\begin{aligned}
\operatorname{Radia} \varepsilon_{c r}= & 1.43 \times 10^{-6} \sigma\left[1-\exp \left(-5 \times 10^{-24} \phi \mathrm{t}\right)\right] \exp \left(1.72 \times 10^{-3} \mathrm{~T}\right. \\
& -0.83)+2.57 \times 10^{-31} \sigma \phi \mathrm{t} \exp \left(1.42 \times 10^{-3} \mathrm{~T}-0.48\right)
\end{aligned}
$$

where $\varepsilon_{\text {cr }}=$ total uniaxial creep strain $(\mathrm{cm} / \mathrm{cm})$,

$\sigma \quad=$ applied uniaxial stress $(\mathrm{kPa})$,

$\phi t=$ fast neutron fluence interval $\left(\mathrm{n} / \mathrm{m}^{2}\right)(\mathrm{E}>29 \mathrm{fJ})_{\mathrm{HTGR}}$,

$\mathrm{T}$ = irradiation temperature $\left({ }^{\circ} \mathrm{C}\right)$.

\subsubsection{Thermal Expansivity}

Figure 4-8 presents the design curve of thermal strain versus temperature for unirradiated $\mathrm{H}-327$ graphite. The data of Fig. 4-6 are tabulated in Table 4-10.

\subsubsection{Thermal Conductivity}

The thermal conductivity of $\mathrm{H}-327$ graphite is calculated using the previously described methodology for $\mathrm{H}-451$ graphite conductivity (Section 4.1.10). The material constants for $\mathrm{H}-327$ graphite to be substituted for Table 4-6 are given in Table 4-11. A plot of the thermal conductivity of H-327 graphite as a function of fast fluence and temperature is given in Fig. 4-7. 
GLP-5588

\section{REFERENCES}

4-1. Butland, A. T. D., and R. J. Maddison, "The Specific Heat of Graphite: An Evaluation of Measurements," J. Nucl. Mater. 49 , $45(1973-74)$.

4-2. Engle, G. B., et a1, "Development Status of Near-Isotropic Graphites for Large HTGRs," USAEC Report GA-A12944, General Atomic Company, June 1, 1974, p. 4 .

4-3. Price, R. J., and L. A. Beavan, "Final Report on Graphite Irradiation Test OG-2," ERDA Report GA-A13556, General Atomic Company, October 1975, pp. 5-1 through 5-43.

4-4. Johnson, W. R., and G. B. Engle, "Properties of Unirradiated Fuel Element Graphites H-451 and TS-1240," ERDA Report GA-A13752, General Atomic Company, January 31, 1976, p. 2

4-5. Price, R. J., "Review of Irradiation-Induced Creep in Graphite under HTGR Conditions," General Atomic Report GA-A12332, November 1, 1974 , p. 49 .

4-6. Price, R. J., "Review of the Thermal Conductivity of Nuclear Graphite under HTGR Conditions," General Atomic Report GA-A12615 (GA-LTR-3), May 3, 1974, pp. 35 through 41.

4-7. "HTGR Fuels and Core Development Program Quarterly Progress Report for the Period Ending August 31, 1977," ERDA Report GA-A14479, General Atomic Company, September 1977, pp. 11-5 and 11-6. 
4-8. Price, R. J., and L. A. Beavan, "Final Report on Graphite Irradiation Test OG-1," USAEC Report GA-A13089, General Atomic Company, August 1, 1974, pp. 13 through 51.

4-9. Price, R. J., and L. A. Beavan, "Final Report on Graphite Irradiation Test OG-3," ERDA Report GA-A14211, Genera1 Atomic Company, January 1977, pp. 5-1 and 5-4.

4-10. Final Safety Analysis Report, Fort St. Vrain, Appendix F.

4-11. Price, R. J., "Mechanica1 Properties of Graphite for High Temperature Gas-Cooled Reactors: A Review," ERDA Report GA-A13524, General Atomic Company, September 22, 1975, pp. 2-6 through 2-9. 
TABLE $4-1$

COEFFICIENTS FOR IRRADIATION STRAIN POLYNOMIAL, H-451 GRAPHITE

\begin{tabular}{|c|c|c|}
\hline Coefficient & Axial & Radial \\
\hline $\mathrm{C}_{1}$ & 0.87602 & 1.00882 \\
\hline $\mathrm{C}_{2}$ & $-0.67267 \times 10^{-2}$ & $-0.71516 \times 10^{-2}$ \\
\hline $\mathrm{C}_{3}$ & $+0.14811 \times 10^{-4}$ & $+0.15042 \times 10^{-4}$ \\
\hline $\mathrm{C}_{4}$ & $-0.12398 \times 10^{-7}$ & $-0.11972 \times 10^{-7}$ \\
\hline $\mathrm{C}_{5}$ & $+0.32775 \times 10^{-11}$ & $+0.30122 \times 10^{-11}$ \\
\hline$c_{6}$ & -0.17040 & -0.14614 \\
\hline$c_{7}$ & $+0.10653 \times 10^{-2}$ & $+0.93781 \times 10^{-3}$ \\
\hline $\mathrm{C}_{8}$ & $-0.21542 \times 10^{-5}$ & $-0.19262 \times 10^{-5}$ \\
\hline $\mathrm{C}_{9}$ & $+0.15310 \times 10^{-8}$ & $+0.13731 \times 10^{-8}$ \\
\hline $\mathrm{C}_{10}$ & $-0.32367 \times 10^{-12}$ & $-0.27741 \times 10^{-12}$ \\
\hline $\mathrm{C}_{11}$ & $+0.23735 \times 10^{-2}$ & $+0.27693 \times 10^{-2}$ \\
\hline$c_{12}$ & $-0.92058 \times 10^{-5}$ & $-0.14285 \times 10^{-4}$ \\
\hline $\mathrm{c}_{13}$ & 0 & $+0.16247 \times 10^{-7}$ \\
\hline $\mathrm{C}_{14}$ & $+0.27754 \times 10^{-10}$ & $+0.10803 \times 10^{-10}$ \\
\hline $\mathrm{C}_{15}$ & $-0.16930 \times 10^{-13}$ & $-0.12287 \times 10^{-13}$ \\
\hline
\end{tabular}


TABLE $4-2$
ULTIMATE TENSILE STRENGTH OF UNIRRADIATED H-451 GRAPHITE AT $25^{\circ} \mathrm{C}$ (a)

\begin{tabular}{c|c}
\hline Orientation & $\begin{array}{c}\text { Mean UTS } \\
{[\mathrm{kPa}(\mathrm{psi})]}\end{array}$ \\
\hline Axial & $13,583(1,970)$ \\
Radia1 & $10,756(1,560)$ \\
\hline
\end{tabular}

(a) From Ref. $4-4$.

TABLE 4-3

ELASTIC MODULUS OF UNIRRADIATED $\mathrm{H}-451$ GRAPHITE AT $25^{\circ} \mathrm{C}$ (a)

\begin{tabular}{c|c}
\hline & $\begin{array}{c}\text { Mean E1astic Modulus }(\mathrm{b}) \\
\left.\text { OrPa }\left(10^{6} \mathrm{psi}\right)\right]\end{array}$ \\
\hline Axial & $7,928,905(1.15)$ \\
Radial & $6,894,700(1.00)$ \\
\hline
\end{tabular}

(a) From Ref. 4-4.

(b) Elastic modulus measured as the mean slope of the stressstrain curve between $689 \mathrm{kPa}(100 \mathrm{psi})$ and 6894 (1000 psi) during the second loading of a specimen which was first loaded to $6894 \mathrm{kPa}$ (1000 psi) and then unloaded to $689 \mathrm{kPa}$ (100 psi). 
TABLE $4-4$

THERMAL EXPANSION OF H-451 GRAPHITE

\begin{tabular}{|c|c|c|}
\hline \multirow{2}{*}{$\begin{array}{c}\text { Temperature } \\
\left({ }^{\circ} \mathrm{C}\right)\end{array}$} & \multicolumn{2}{|c|}{ Thermal Strain $\left(10^{-3} \mathrm{~cm} / \mathrm{cm}\right)$} \\
\hline & Axial & Radial \\
\hline $\begin{array}{r}25 \\
100 \\
150 \\
200 \\
250 \\
300 \\
350 \\
400 \\
450 \\
500 \\
550 \\
600 \\
650 \\
700 \\
750 \\
800 \\
850 \\
900 \\
950 \\
1000 \\
1050 \\
1100 \\
1150 \\
1200 \\
1250 \\
1300 \\
1350 \\
1400 \\
1450 \\
1500 \\
1550 \\
1600\end{array}$ & $\begin{array}{l}0 \\
0.26 \\
0.42 \\
0.60 \\
0.80 \\
1.0 \\
1.2 \\
1.42 \\
1.65 \\
1.88 \\
2.12 \\
2.35 \\
2.6 \\
2.83 \\
3.1 \\
3.35 \\
3.58 \\
3.84 \\
4.1 \\
4.33 \\
4.60 \\
4.88 \\
5.14 \\
5.42 \\
5.7 \\
6.0 \\
6.3 \\
6.6 \\
6.9 \\
7.24 \\
7.55 \\
7.9\end{array}$ & $\begin{array}{l}0 \\
0.32 \\
0.52 \\
0.74 \\
0.95 \\
1.2 \\
1.43 \\
1.68 \\
1.93 \\
2.19 \\
2.46 \\
2.75 \\
3.03 \\
3.32 \\
3.58 \\
3.88 \\
4.16 \\
4.41 \\
4.73 \\
5.06 \\
5.32 \\
5.62 \\
5.91 \\
6.23 \\
6.53 \\
6.85 \\
7.16 \\
7.5 \\
7.85 \\
8.20 \\
8.52 \\
8.9\end{array}$ \\
\hline
\end{tabular}


TABLE 4-5

TEMPERATURE-DEPENDENT CONDUCTIVITY COMPONENTS

(Ref. Eq. 4-4)

Units $=\left(\mathrm{cal} / \mathrm{cm}-\mathrm{s}-{ }^{\circ} \mathrm{C}\right) \times$ (Scale Factor)

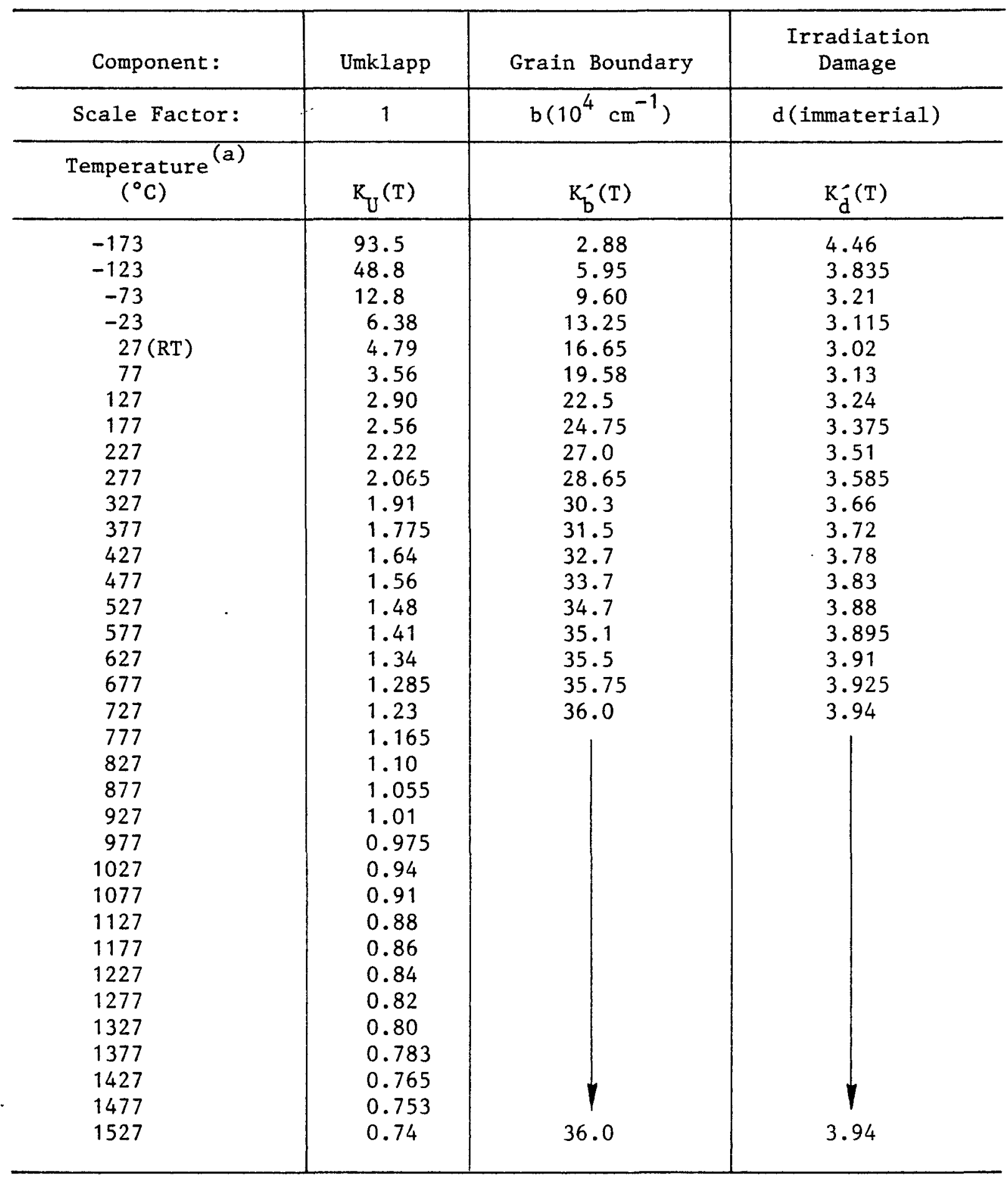

(a) The temperature points are equally spaced in order to facilitate the linear interpolation. 
TABLE $4-6$

MATERIAL CONSTANTS FOR CALCULATION OF NEAR-ISOTROPIC

GRAPHITE THERMAL CONDUCTIVITY

\begin{tabular}{c|c|c|c|c}
\hline \multirow{2}{*}{ Symbo1 } & \multirow{2}{*}{ Ref. Eq. } & \multicolumn{2}{|c|}{ Value } & \multirow{2}{*}{ Units (a) } \\
\cline { 2 - 5 } & $4-8$ & -0.3059 & -0.3059 & $10^{25} \mathrm{n} / \mathrm{m}^{2}$ \\
A & $4-8$ & $9.58 \times 10^{-4}$ & $9.58 \times 10^{-4}$ & $10^{25} \mathrm{n} / \mathrm{m}^{2}-{ }^{\circ} \mathrm{C}$ \\
B & $4-9$ & -3.317 & -3.430 & - \\
D & $4-9$ & $1.207 \times 10^{-3}$ & $1.222 \times 10^{-3}$ & ${ }^{\circ} \mathrm{C}^{-1}$ \\
a & $4-4$ & 5.334 & 5.707 & - \\
b & $4-4$ & 5.192 & 6.165 & $10^{4} \mathrm{~cm}^{-1}$ \\
\hline
\end{tabular}

(a) Neutron fluence units $\left(10^{25} \mathrm{n} / \mathrm{m}^{2}\right)$ are in terms of HTGR fast fluence (E $\geq 29 \mathrm{fJ}^{\text {HTGR }}$. 
TABLE 4-7

COEFFICIENTS FOR IRRADIATION STRAIN POLYNOMIAL, H-327 GRAPHITE

\begin{tabular}{|c|c|c|}
\hline & Axial & Radial \\
\hline$c_{1}$ & -6.901536 & 0.122708 \\
\hline $\mathrm{C}_{2}$ & $+0.214790 \times 10^{-1}$ & $+0.225189 \times 10^{-2}$ \\
\hline $\mathrm{C}_{3}$ & $-0.209455 \times 10^{-4}$ & $-0.842109 \times 10^{-5}$ \\
\hline $\mathrm{C}_{4}$ & $+0.615816 \times 10^{-8}$ & $+0.941604 \times 10^{-8}$ \\
\hline $\mathrm{C}_{5}$ & 0 & $-0.360083 \times 10^{-11}$ \\
\hline $\mathrm{c}_{6}$ & +0.718380 & -0.265774 \\
\hline $\mathrm{c}_{7}$ & $-0.209419 \times 10^{-2}$ & $-0.531424 \times 10^{-3}$ \\
\hline $\mathrm{c}_{8}$ & $+0.179240 \times 10^{-5}$ & $+0.344720 \times 10^{-5}$ \\
\hline $\mathrm{C}_{9}$ & $-0.485434 \times 10^{-9}$ & $-0.427347 \times 10^{-8}$ \\
\hline $\mathrm{c}_{10}$ & 0 & $+0.162954 \times 10^{-11}$ \\
\hline $\mathrm{c}_{11}$ & $-0.356955 \times 10^{-2}$ & $+0.725128 \times 10^{-1}$ \\
\hline $\mathrm{C}_{12}$ & $+0.605363 \times 10^{-5}$ & $-0.164812 \times 10^{-3}$ \\
\hline $\mathrm{C}_{13}$ & 0 & 0 \\
\hline $\mathrm{C}_{14}$ & 0 & $+0.204765 \times 10^{-9}$ \\
\hline$c_{15}$ & 0 & $-0.108765 \times 10^{-12}$ \\
\hline
\end{tabular}


GLP -5588

TABLE 4-8

ULTIMATE TENSILE STRENGTH OF UNIRRADIATED H-327 GRAPHITE

\begin{tabular}{c|c}
\hline Orientation & $\begin{array}{c}\text { Mean UTS } \\
{[\mathrm{kPa}(\mathrm{psi})]}\end{array}$ \\
\hline Axial & $11,238(1,630)$ \\
Radial & $6,481(940)$ \\
\hline
\end{tabular}

TABLE 4-9

ELASTIC MODULUS OF UNIRRADIATED H-327 GRAPHITE

\begin{tabular}{c|c}
\hline & $\begin{array}{c}\text { Mean Elastic Modulus } \\
\text { Orientation }\end{array}$ \\
\hline Axial \\
Radial & $10,342,050(1.5)$ \\
Rsi $)]$ \\
\hline
\end{tabular}


TABLE $4-10$

THERMAL EXPANSION OF H-327 GRAPHITE

\begin{tabular}{|c|c|c|}
\hline \multirow{2}{*}{$\begin{array}{c}\text { Temperature } \\
\left({ }^{\circ} \mathrm{C}\right)\end{array}$} & \multicolumn{2}{|c|}{ Thermal Strain $\left(10^{-2} \mathrm{~cm} / \mathrm{cm}\right)$} \\
\hline & Axial & Radial \\
\hline 50 & 0 & 0.005 \\
\hline 100 & 0.003 & 0.016 \\
\hline 150 & 0.007 & 0.030 \\
\hline 200 & 0.012 & 0.044 \\
\hline 250 & 0.017 & 0.059 \\
\hline 300 & 0.023 & 0.076 \\
\hline 350 & 0.031 & 0.092 \\
\hline 400 & 0.039 & 0.109 \\
\hline 450 & 0.048 & 0.127 \\
\hline 500 & 0.057 & 0.146 \\
\hline 550 & 0.067 & 0.166 \\
\hline 600 & 0.080 & 0.186 \\
\hline 650 & 0.091 & 0.206 \\
\hline 700 & 0.104 & 0.227 \\
\hline 750 & 0.117 & 0.249 \\
\hline 800 & 0.131 & 0.270 \\
\hline 850 & 0.145 & 0.293 \\
\hline 900 & 0.160 & 0.315 \\
\hline 950 & 0.175 & 0.338 \\
\hline 1000 & 0.191 & 0.362 \\
\hline 1050 & 0.207 & 0.385 \\
\hline 1100 & 0.223 & 0.408 \\
\hline 1150 & 0.240 & 0.432 \\
\hline 1200 & 0.256 & 0.456 \\
\hline 1250 & 0.273 & 0.480 \\
\hline 1300 & 0.291 & 0.504 \\
\hline 1350 & 0.311 & $0.529^{\circ}$ \\
\hline 1400 & 0.329 & 0.556 \\
\hline 1450 & 0.348 & 0.582 \\
\hline 1500 & 0.368 & 0.611 \\
\hline 1550 & 0.391 & 0.640 \\
\hline 1600 & 0.412 & 0.670 \\
\hline
\end{tabular}


TABLE 4-11

MATERIAL CONSTANTS FOR CALCULATION OF H-327 THERMAL CONDUCTIVITY

\begin{tabular}{c|c|c|c}
\hline \multirow{2}{*}{ Symbo1 } & \multicolumn{2}{|c|}{ Value } & \multirow{2}{*}{ Units } \\
\cline { 2 - 4 } & Axial & Radial & $10^{25} \mathrm{n} / \mathrm{m}^{2}$ \\
A & -0.3059 & -0.3059 & $10^{25} \mathrm{n} / \mathrm{m}^{2}$ \\
B & $9.58 \times 10^{-4}$ & $9.58 \times 10^{-4}$ & - \\
C & -3.429 & -4.215 & ${ }^{\circ} \mathrm{C}^{-1}$ \\
D & $1.305 \times 10^{-3}$ & $1.821 \times 10^{-3}$ & - \\
b & 4.774 & 6.875 & $10^{4} \mathrm{~cm}^{-1}$ \\
\hline
\end{tabular}




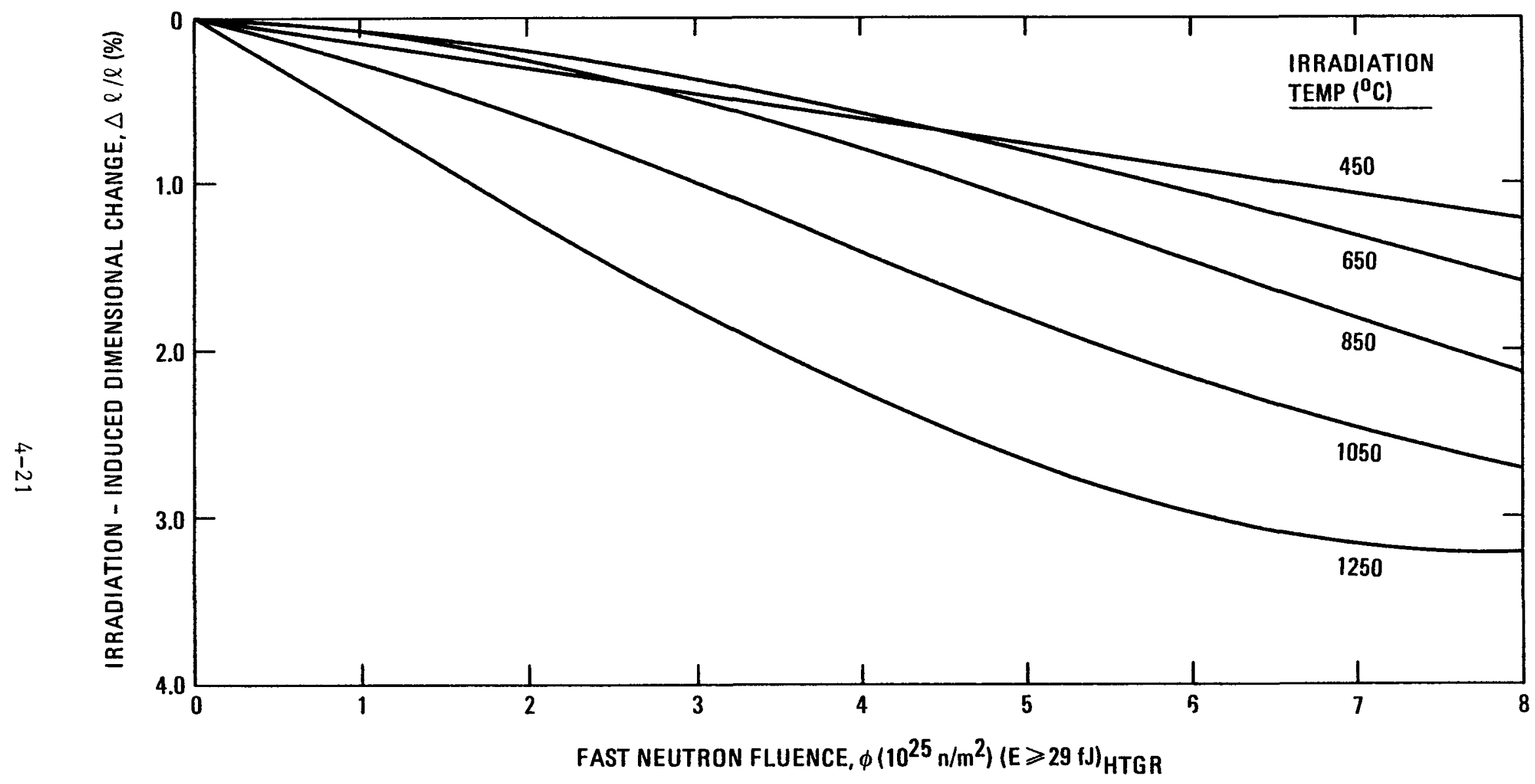

Fig. 4-1. Irradiation strain versus fast neutron fluence and irradiation temperature in near-isotropic graphite; axial orientation, calculated by using Eq. 4-2 


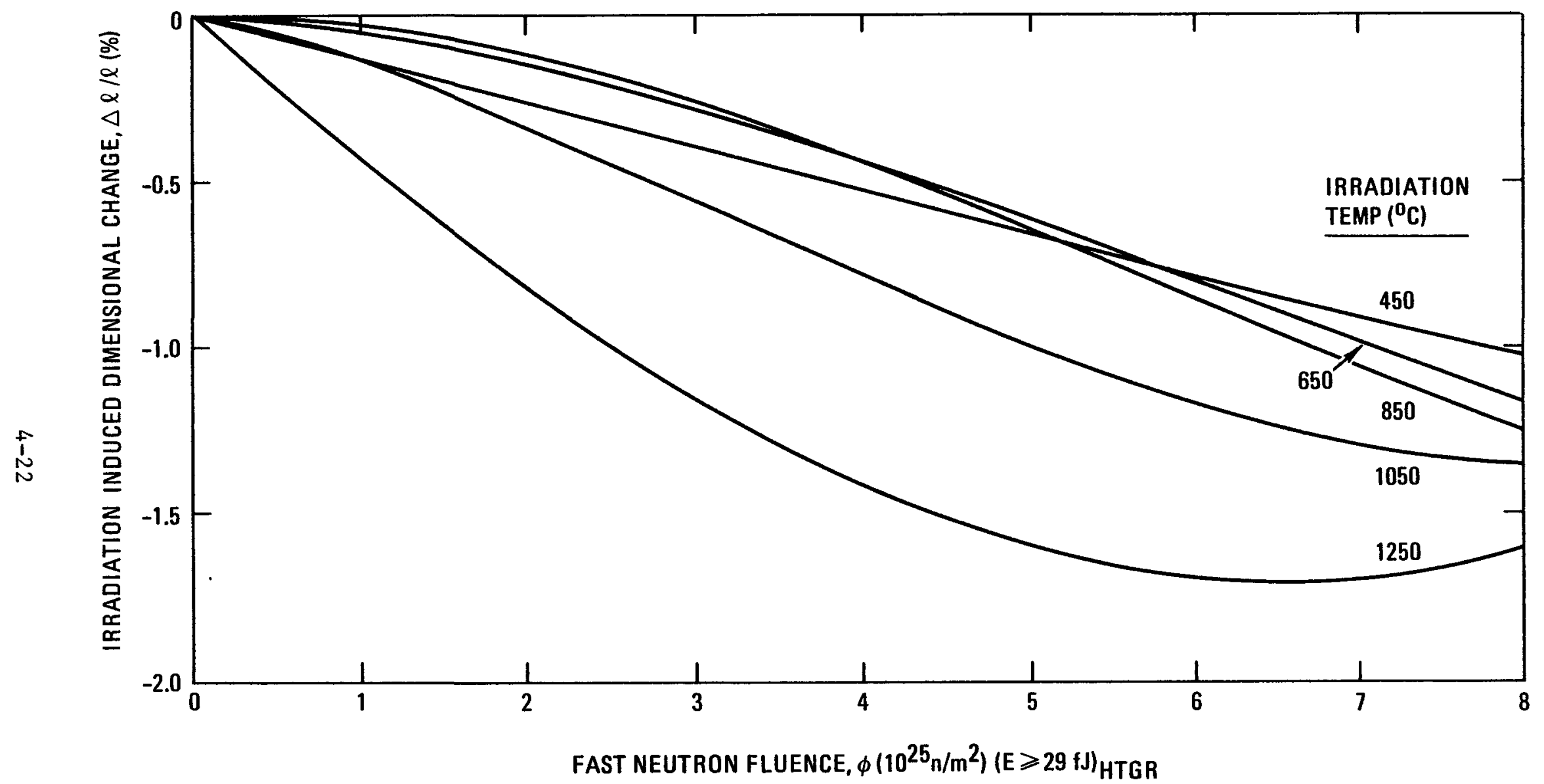

Fig. 4-2. Irradiation strain versus fast neutron fluence and irradiation temperature in near-isotropic graphite; radial orientation, calculated by using Eq. 4-2 


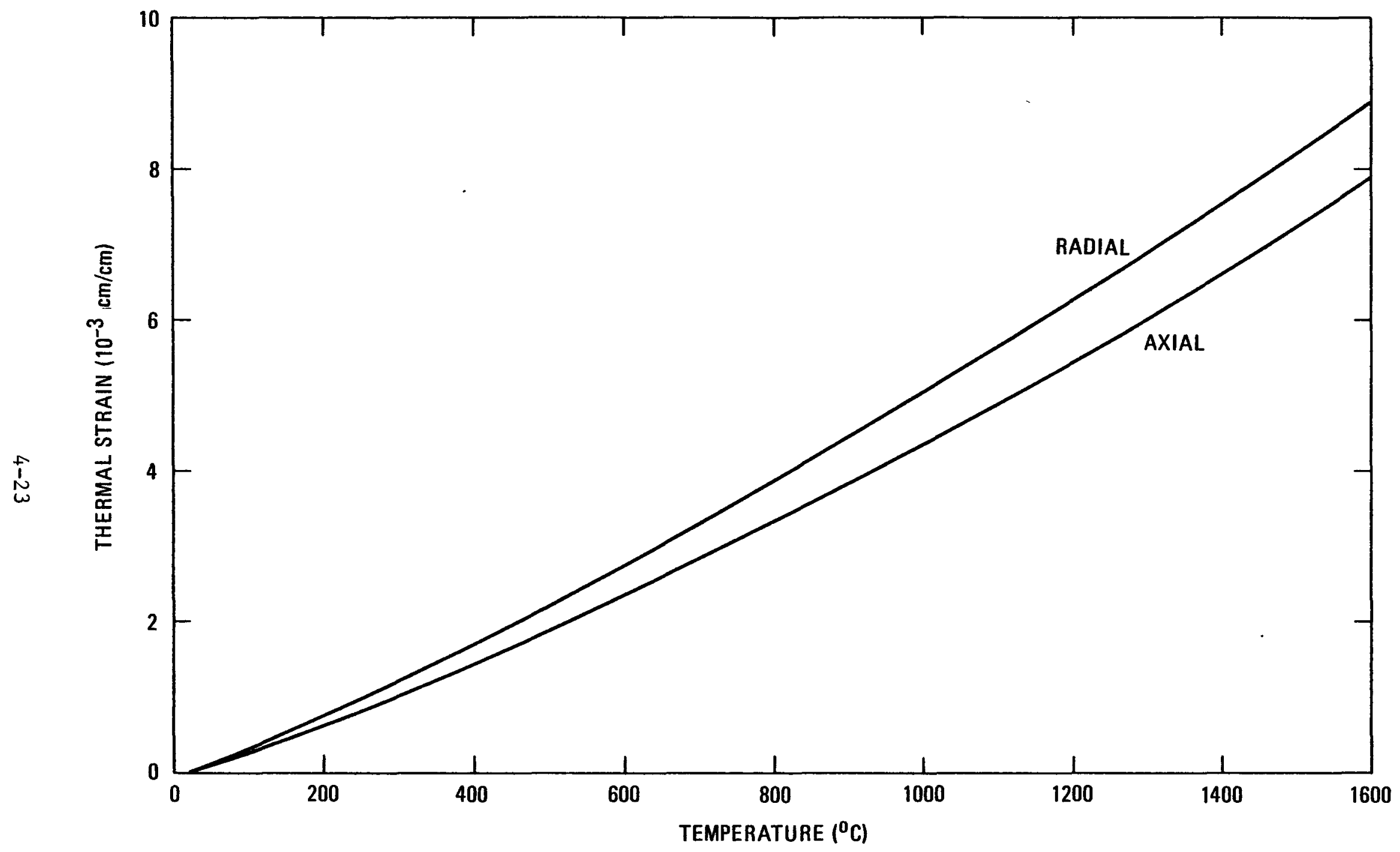

Fig. 4-3. Thermal strain (expansion) of H-451 near-isotropic graphite, from data given in Table 4-4 


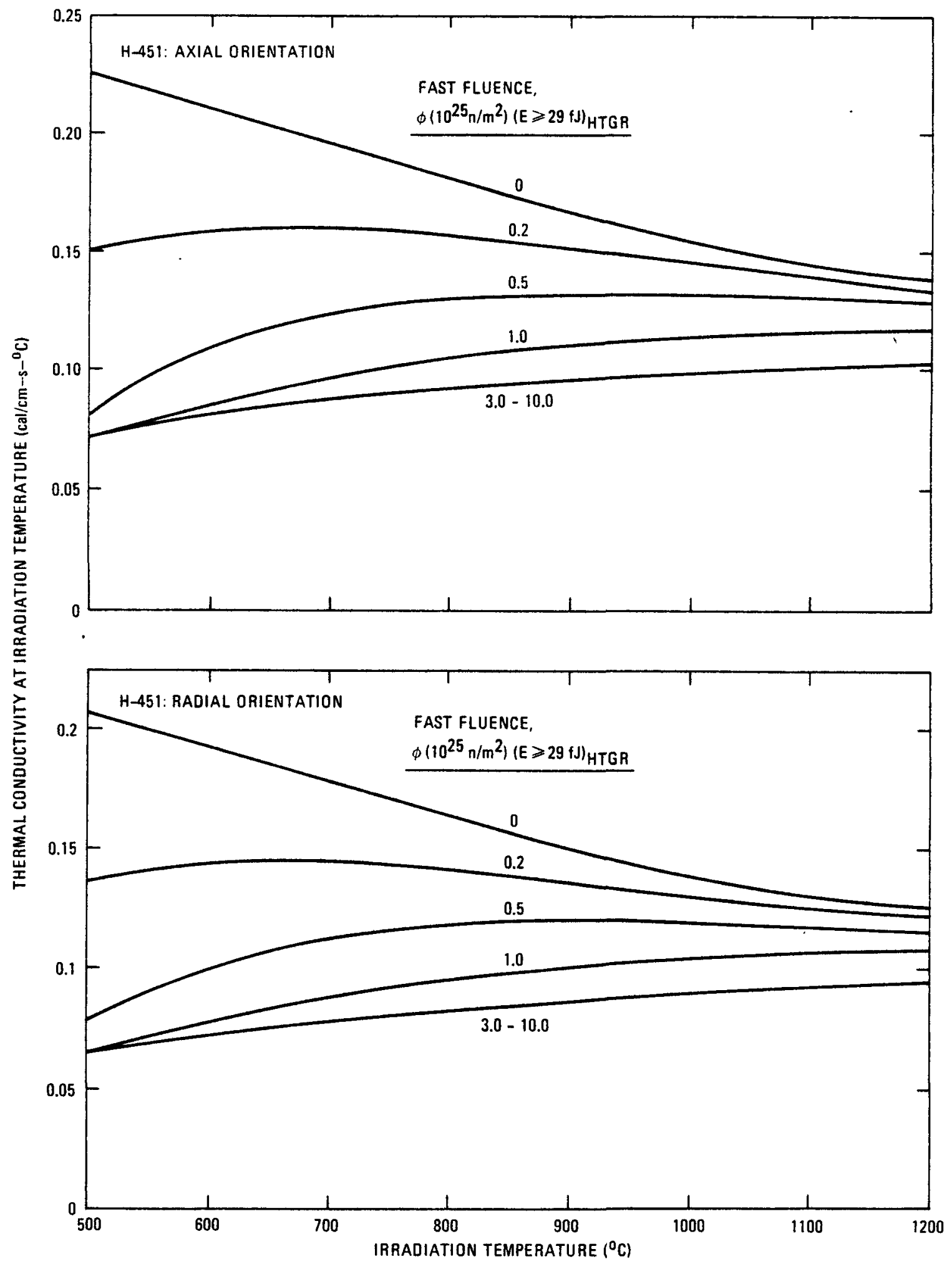

Fig. 4-4. Thermal conductivity of irradiated H-451 graphite 


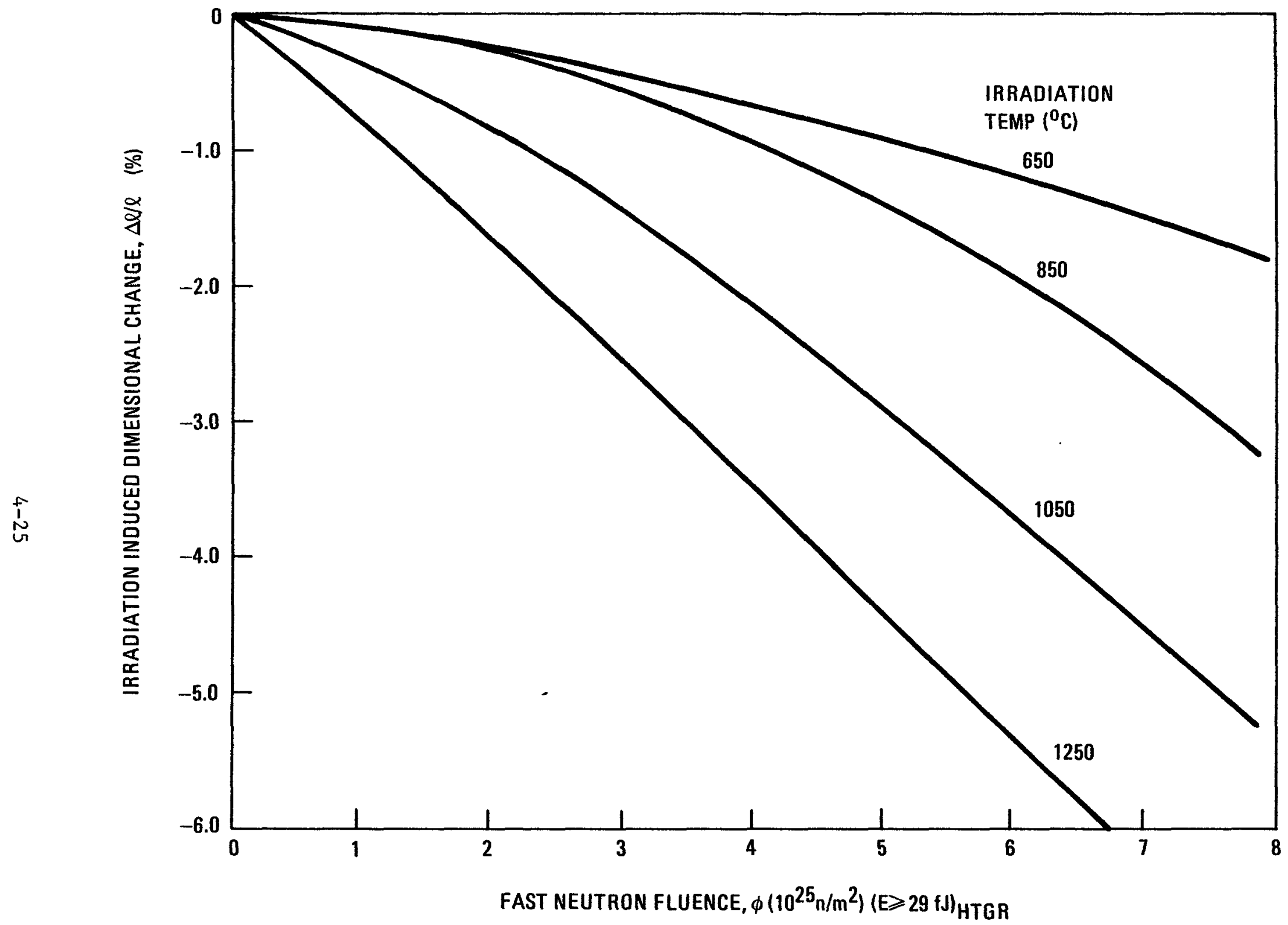

Fig. 4-5. Irradiation-induced dimensional change: (a) H-327, axial 


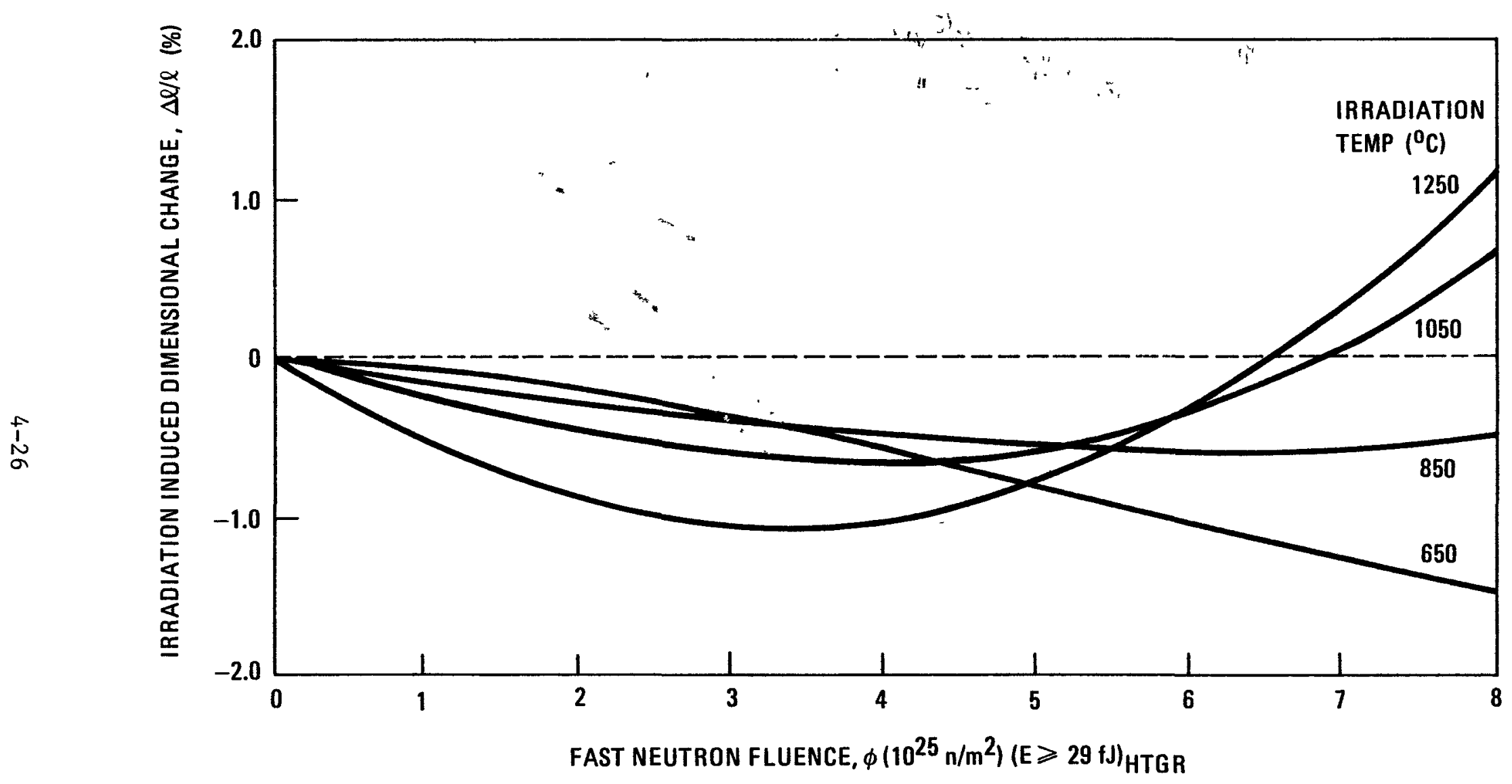

Fig. 4-5. Irradiation-induced dimensional change: (b) $\mathrm{H}-327$, radial 


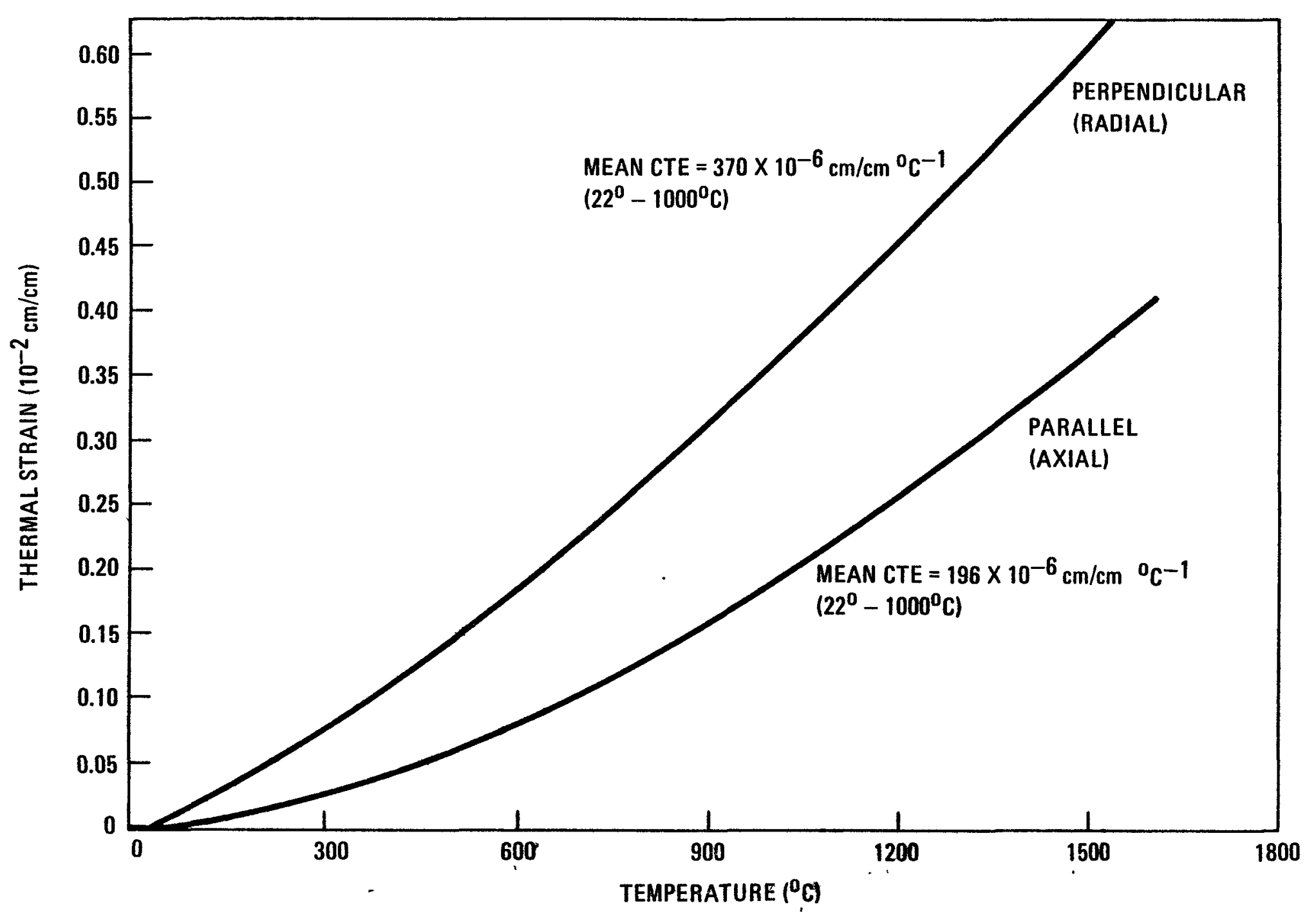

Fig. 4-6. H-327 graphite thermal expansion from data given in Table 4-10 


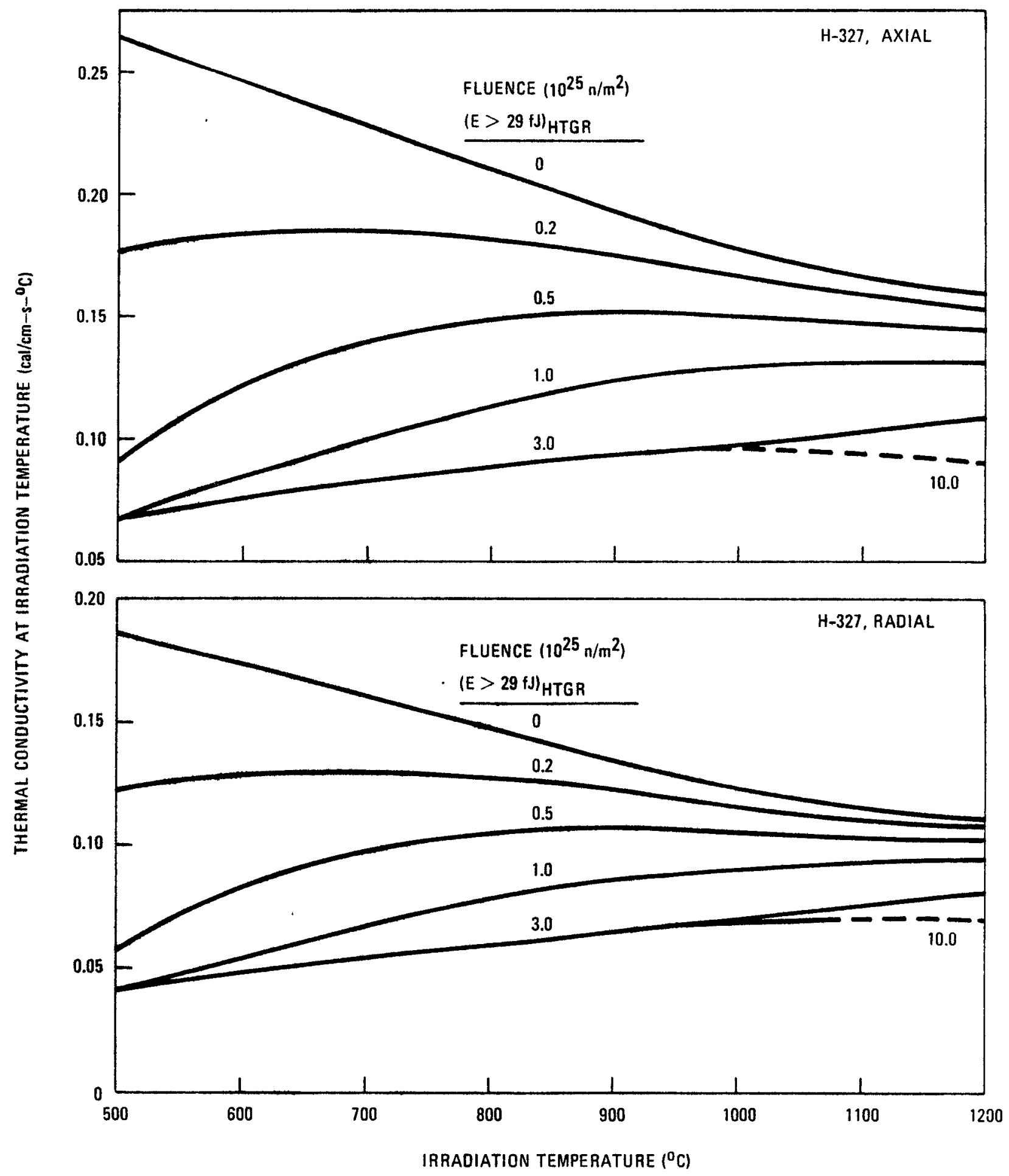

Fig. 4-7. Calculated thermal conductivity of irradiated H-327 needlecoke graphite 
STANDARD DISTRIBUIION FOR AII MATQRIAI SUBMIIIED ALI

NRC FORM 195

U.S. NUCLEAR REGULATORY COMMISSION DOCKET YUMBER

(2.76)

NRC DISTRIBUTION FOR PART 50 DOCKET MATERIAL

TO:Mr. R. P. Denise

FROM: General Atomic Company

San Diego, Ca. 92138

G.L. Wessman

FILE NUMBER

DATE OF DOCUMENT

$3-28-78$

DATE REFEIVED

NUMBER OF COPIES RECEIVED

LETTEa
DoRiginal
DCOPY

\begin{tabular}{l|l}
\hline PROP & INPUT FORM
\end{tabular}

3 SIGNCO

OESCRIPTION LET notarized 3-28-78 trans the following: $2 \mathrm{P}$

ENCLOSURE GLP-5588 entitled "Safety Analysis

Report Use of H-451 Graphite in Fort St. Vrain

Fuel Elements"......50P est....

\section{PLANT IIAME:}

DISTRIBUTION RECEIVED 4-7-78

DERISE

P. WIIIIAMS

G. KUZMIYZZ

H. GRARIT

\section{SUBJeat}

FIIES

NRC PDR

I\&d $1+16)$

OFT

MIPC

R. A. CIAAKK

JP ENIGHT

ROSS

THTESCO

BETAROYA

IPPOLTIO

ST:MTIO

BUNCE

J. COIITIS

KREGEIR

IXIIND

\section{FOR ACTION/INFORMATION}

\begin{tabular}{|l|l|l|l|}
\hline & & \\
\hline & & & \\
\hline & & & \\
\hline
\end{tabular}

INTERNAL DISTRIBUTION

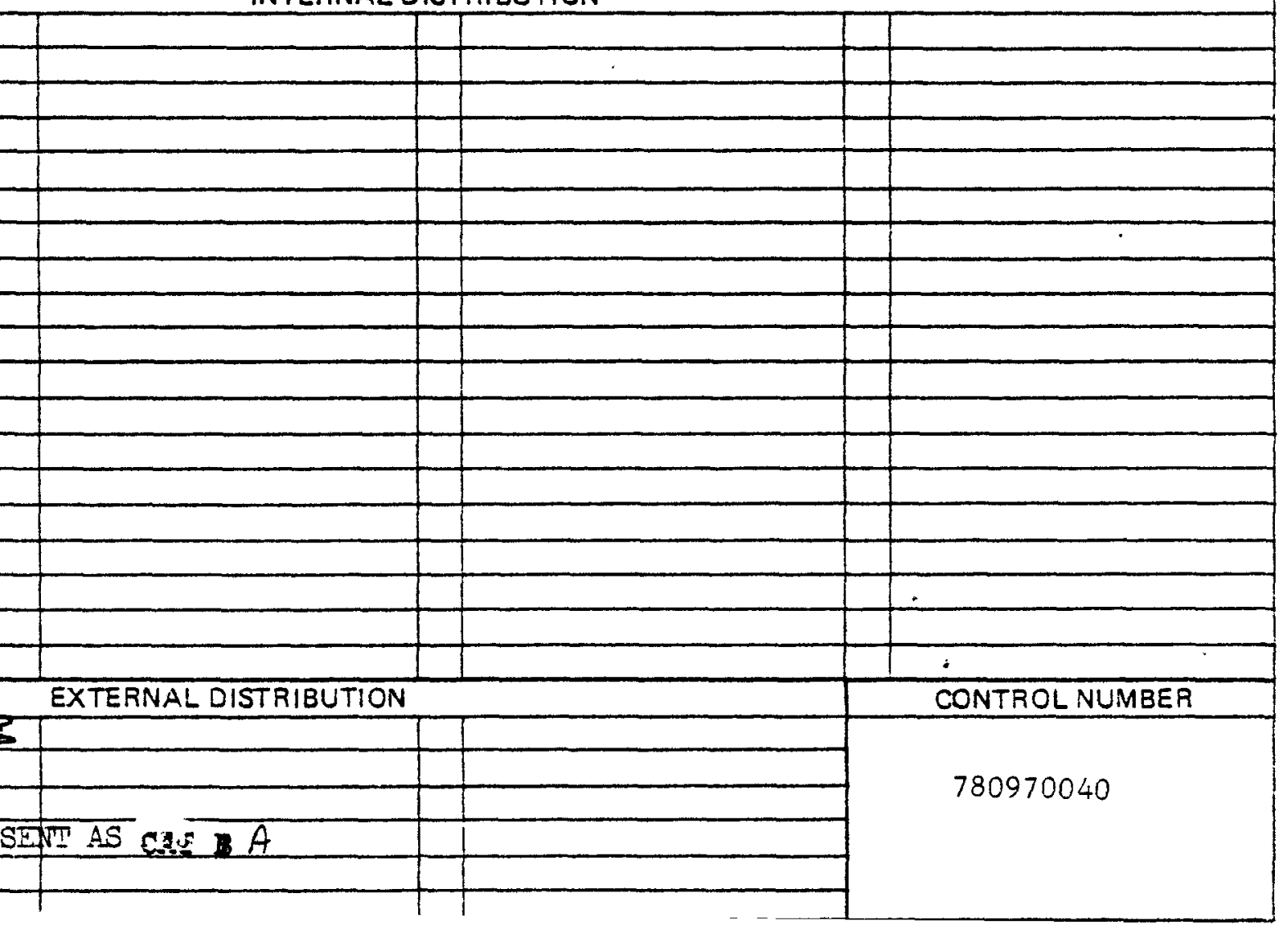


U. S. Nuclear Regulatory Commission

Director of Nuclear Reactor Regulation

Washington, D.C. 20555

Attention: Mr. R. P. Denise, Assistant Director, Special Projects

Dear Sir:

Transmitted with this letter are fifty (50) copies of "Safety Analys is Report Use of H-457 Graphite in Fort St. Vrain Fuel Elements," Document No. GLP-5588, December 20, 1977.

You are requested to review this report and concur with the conclusion presented in the report that a substitution of type H-451 graphite in the Fort St. Vrain reactor for the type H-327 currently used is acceptable. We intend to substitute the type $\mathrm{H}-451$ graphite in the fuel elements.

General Atomic Company is contractualiy obligated to supply Public Service Company of Colorado with fuel elements. It is our intent to use $\mathrm{H}-451$ graphite to fulfill this contract as soon as practicable after receiving your approval. The final determination of the exact reload and schedule on which this substitution will be made, as well as any information required by the Nuclear Regulatory Commission associated with the specific reload, is the responsibility of Public Service Company of Colorado.

General Atomic Company believes the approval of $\mathrm{H}-451$ graphite is required for us to comply with our contract for several reasons. First, it does not appear that the H-327 graphite, the type currentiy used, will be available in the future. Secondly, we believe that type $\mathrm{H}-451$ graphite is a superior material both in terms of dimensional stability under irradiation and strangth.

We are requesting that you complete your review of this topic by December 1, 1978. This would allow us to specify $\mathrm{H}-451$ in our next purchase of graphite for the Fort St. Vrain reactor. 
U. S. Nuclear Regulatory Commission -2- March 28, 1978

Your cooperation in meeting this schedule would be greatly appreciated. General Atomic Company stands ready to supply additional information as required for you to complete your review.

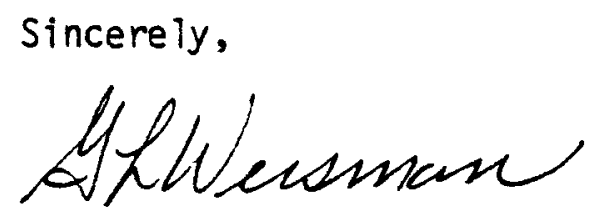

G. L. Wessman, Director

Plant Licensing Division

\section{Enclosures}

\section{STATE OF CALIFORNLA） \\ 188. \\ COUNTY OF SAN DIEGO )}

After being duly sworn, the person known to me to be G. L. Wessman of General Atomic Company, signed the above document this 28th day of March 1978.

WITNESS my hand and official seal.
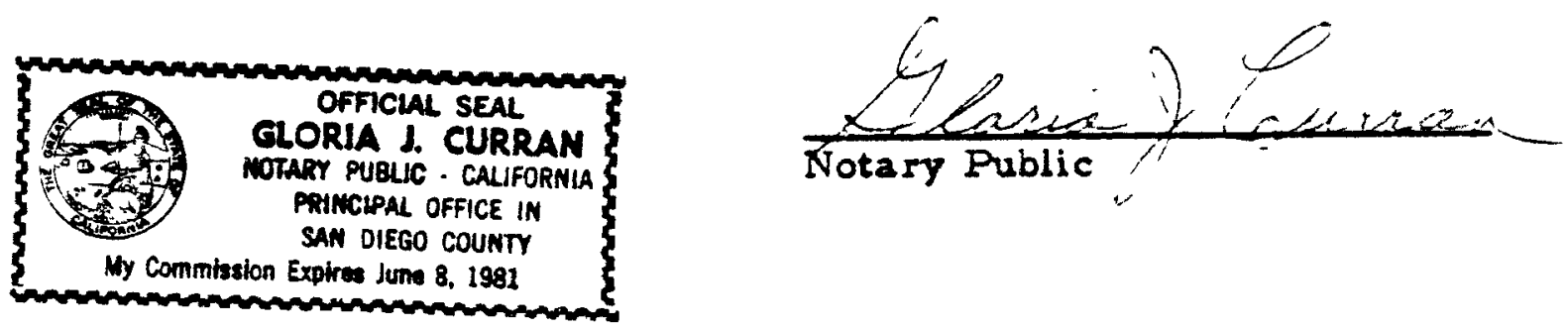